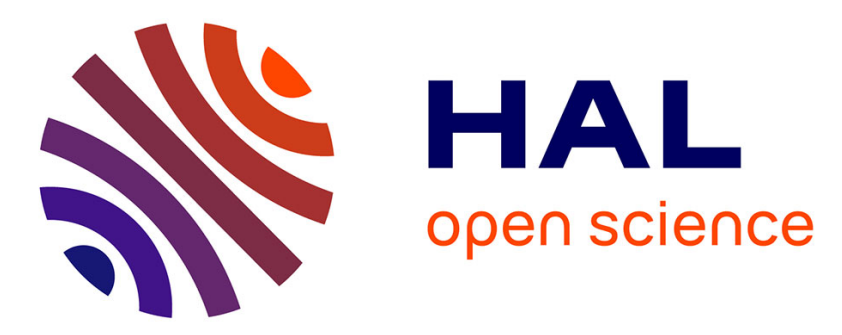

\title{
A Planar Anode - Supported Solid Oxide Fuel Cell Model with Internal Reforming of Natural Gas
} Penyarat Chinda, Somchai Chanchaona, Pascal Brault, Wishsanuruk Wechsatol

\section{- To cite this version:}

Penyarat Chinda, Somchai Chanchaona, Pascal Brault, Wishsanuruk Wechsatol. A Planar Anode Supported Solid Oxide Fuel Cell Model with Internal Reforming of Natural Gas. European Physical Journal: Applied Physics, 2011, 54, 23405 (15p.). 10.1051/epjap/2011100145 . hal-00594667

\section{HAL Id: hal-00594667 https://hal.science/hal-00594667}

Submitted on 20 May 2011

HAL is a multi-disciplinary open access archive for the deposit and dissemination of scientific research documents, whether they are published or not. The documents may come from teaching and research institutions in France or abroad, or from public or private research centers.
L'archive ouverte pluridisciplinaire HAL, est destinée au dépôt et à la diffusion de documents scientifiques de niveau recherche, publiés ou non, émanant des établissements d'enseignement et de recherche français ou étrangers, des laboratoires publics ou privés. 


\title{
A Planar Anode - Supported Solid Oxide Fuel Cell Model with Internal Reforming of Natural Gas
}

\author{
Penyarat Chinda ${ }^{1}$, Somchai Chanchaona ${ }^{1}$, Pascal Brault ${ }^{2, *}$ and Wishsanuruk Wechsatol ${ }^{1, *}$ \\ ${ }^{1}$ Department of Mechanical Engineering, King Mongkut's University of Technology Thonburi, \\ 126 Pracha-utid Road, Bangmod, Thungkru, Bangkok, 10140, Thailand \\ ${ }^{2}$ Groupe de Recherche sur l'énergétique des Milieux Ionisés (GREMI), \\ UMR 6606 CNRS-Université d'Orléans, BP6744, 45067, Orléans Cedex 2, France \\ *Corresponding author: pascal.brault@univ-orleans.fr
}

\begin{abstract}
Solid Oxide Fuel Cells (SOFCs) are of great interest due to their high energy efficiency, low emission level, and multiple fuel utilization. SOFC can operate with various kinds of fuels such as natural gas, carbon monoxide, methanol, ethanol, and hydrocarbon compounds, and they are becoming one of the main competitors among environmentally friendly energy sources for the future. In this study, a mathematical model of a co - flow planar anode - supported solid oxide fuel cell with internal reforming of natural gas has been developed. The model simultaneously solves mass, energy transport equations, and chemical as well as electrochemical reactions. The model can effectively predict the compound species distributions as well as the cell performance under specific operating conditions. The main result is a rather small temperature gradient obtained at $800^{\circ} \mathrm{C}$ with $\mathrm{S} / \mathrm{C}=1$ in classical operating conditions. The cell performance is reported for several operating temperatures and pressures. The cell performance is specified in terms of cell voltage and power density at any specific current density. The influence of electrode microstructure on cell performance was investigated. The simulation results show that the steady state performance is almost insensitive to microstructure of cells such as porosity and tortuosity unlike the operating pressure and temperature. However, for SOFC power output enhancement, the power output could be maximized by adjusting the pore size to an optimal value, similarly to porosity and tortuosity. At standard operating pressure (1 atm) and 800
\end{abstract}


${ }^{\circ} \mathrm{C}$ with $48 \%$ fuel utilization, when an output cell voltage was 0.73 volt, a current density of 0.38 A.cm ${ }^{-2}$ with a power density of $0.28 \mathrm{~W} . \mathrm{cm}^{-2}$ was predicted. The accuracy of the model was validated by comparing with existing experimental results from the available literature.

Keywords: SOFC, mathematical model, anode - supported, cell performance, microstructure, internal reforming

\section{Introduction}

Solid Oxide Fuel Cell (SOFC) is a highly efficient energy conversion device that transforms chemical energy to electrical energy and heat directly from fuels through the electrochemical reactions of fuels and oxidants. The fuel can be natural gas, carbon monoxide, methanol, ethanol and hydrocarbon compounds as well as $\mathrm{H}_{2}$. The SOFC can be used with a variety of power generation systems; both stationary power generators or auxiliary power sources in automobiles, in aircrafts or even in residential applications [1,2]. One cell consists of interconnected structures and a three layered region composed of two ceramic electrodes (anode and cathode) separated by a dense ceramic electrolyte. SOFCs operate at high temperatures in the range 800 to $1000^{\circ} \mathrm{C}[1,2]$ and both atmospheric or elevated pressures and can utilize a variety of fuels. Oxygen ions formed at the cathode migrate through the ion - conducting electrolyte to the anode/electrolyte interface where they react with the fuel gases, producing water while releasing electrons that flow via an external circuit to the cathode/electrolyte interface. Flexibility in fuel utilization is an advantage of SOFCs over other types of fuel cells. Hydrocarbon fuels can be supplied directly to SOFCs without the need for pre reforming processing $[1,2]$. In this work, we focus on the mathematical modeling of SOFC behaviors and performance with direct internal reforming.

This work is concerned in the planar type SOFC, which provides higher power density than the tubular type [2] due to its shorter current flow path and lower ohmic overpotential. Moreover, the 
planar SOFC is easier to fabricate and can be manufactured in various configurations [1,2]. The cell support can be either cathode - supported or anode - supported type. However, many research organizations have shown that the anode - supported design leads to better cell performance than the cathode - supported one [3,4]. The planar design consists of cell components configured as thin planar plates. Common plate shapes are rectangular or square. Gas manifolding can be divided into 3 configurations, which are co-flow, counter-flow and cross-flow designs. However, the status of the development is still at a module level, and some technical issues have not been solved yet. The internal stresses in cell components arising from thermal shocks or heat cycles are one of the problems to be solved. The planar type SOFC requires high temperature gas seals at the edges or around the internal gas manifolds. For this propose cemet, glass and glass - ceramic seals are expected to give sufficient sealing efficiency. However, the strict binding among each cell component generates mechanical constraints, and thus a slight mismatch in thermal expansion coefficient among the cell components can cause an immense stress. Moreover, because of non - homogeneous temperature distribution inside the cell, cell component are irregularly deformed, adding a large internal stress. As a consequence, the thermal expansion coefficient matching among the cell components and mitigation of the non - homogeneous temperature distributions in the cell components are indispensable to reduce the internal stress. Some parameters of cell design, stack design and operating conditions, such as cell geometry, internal or external steam reforming, thermal conductivity of the component and cell operating voltage affect the temperature distributions inside the cells in a complicated way, and thus creates difficult to optimize these parameters independently to lower the internal stresses. One method to reduce the internal stresses and the gas sealing problems, is to reduce the operating temperature to intermediate range around 600 to $800^{\circ} \mathrm{C}$.. Thinner electrolytes are expected to reduce the ohmic loss. In this work, we examine the anode - supported SOFC type due to the suitability of its configuration for direct internal reforming of hydrocarbon fuels. Natural gas was used as the fuel supply in this 
study. The reforming process inside the anode occurs through a steam - methane reforming reaction and water - gas shift reaction [3].

Various models of gas transport inside thick porous anodes have been proposed by several researchers. Yakabe et al. [4] and Lehnert et al. [5] applied a mass transport model similar to the dusty - gas model (DGM) in their computational model. Suwanwarangkul et al. [6] compared accuracy in gas transport phenomena inside anodes of three different models: Fick's law model (FM), Stefan Maxwell model (SMM), and the dusty - gas model (DGM). Among the three models, the dusty - gas model provided the greatest accuracy in predicting gas transport behavior inside the anode when compared with experimental data on the mass transport of $\mathrm{H}_{2}-\mathrm{H}_{2} \mathrm{O}-\mathrm{Ar}$ and $\mathrm{CO}-\mathrm{CO}_{2}$. Unlike Yakabe et al. and Lehnert et al, the water - gas shift reaction was omitted by Suwanwarangkul et al. Ackmann et al. [7] applied the mean transport pore model (MTPM) to analyze mass transport in a two - dimensional cell model. They included the effects of chemical and electrochemical reactions on heat transfer and temperature distribution inside the cell. Aguiar et al. [3] investigated the performance of an anode - supported SOFC with direct internal reforming for co- and counter-flow configurations. The results showed that with the same fuel and air inlet conditions, the counter - flow configuration gave rise to the least optimal operation due to steep temperature gradients and uneven current density distributions. However, the model used was one-dimensional and was for the cell working at intermediate temperatures $\left(650{ }^{\circ} \mathrm{C}-800{ }^{\circ} \mathrm{C}\right)$. Morel et al. [8] studied the direct internal reforming (DIR) process of methane within the thick porous anode of SOFC, based on the previously mentioned model. Like Ackmann, they used the dusty - gas model and studied thermal approaches in which heat sources are derived from the methane - steam reforming reaction, water - gas shift reaction, and electrochemical reaction, while taking into account mass transport along the gas channels and diffusion through the porous electrodes, as proposed by Lehnert et al [5, 7]. 
Nikooyeh et al. [9] presented a 3D model where the steam-to-carbon ratio, which is known to dominate the propensity for carbon deposition on the anode cermet, was evaluated. However, it remained un-clear where exactly in the anode the heat generated by the electrochemical reactions should be applied. Pramuanjaroenkij et al. [10] presented a 2D model for analyzing the performance of a planar SOFC fed by $\mathrm{H}_{2}$ mixed with $\mathrm{H}_{2} \mathrm{O}$ to the anode channel. The co-flow configuration was considered. With the electrolyte material of yttria stabilized zirconia, a cell with anode - supported design was shown to give higher power density in the high current density range than that with electrolyte - supported design at $800^{\circ} \mathrm{C}$. Recently, Ho et al. [11] developed a 3D model for SOFCs with composite electrodes applied to an anode - supported cell working under direct internal reforming conditions. In the model, the methane reforming reaction was assumed to take place mostly in the bulk of the porous anode, and the electrochemical reactions take place in regions of finite thickness adjacent to the dense electrolyte. Coupled equations describing the conservation of mass, momentum and energy as well as the chemical and electrochemical processes were solved in a single 3D computational domain by using Star-CD. The results showed that for co-flow configuration, a subcooling effect manifests itself in the methane-rich region near the fuel entrance, while for counterflow configuration a super-heating effect manifests itself somewhat further downstream, where all the methane is consumed. All results in their work that are temperature, chemical species and current density distribution are presented in the form of mean values. However, their work was excluding the influence of electrode microstructure and operating conditions of the cell. Later, Ho et al. [12] developed a 3D model of SOFCs with composite electrodes to investigate the performance of a planar cathode - supported solid oxide fuel cell (SOFC). The methane reforming reaction was included in the model and assumes to take place mostly in the porous thin anode at the high operating temperature of $800{ }^{\circ} \mathrm{C}-1000^{\circ} \mathrm{C}$. The equations governing transports and chemical and electrochemical reactions were solved by using Star-CD. An improvement of the model, ohmic heating effect due to resistances 
to current flows in solid parts of the cell, was taken into account. Results of temperature, chemical species, current density and electric potential distribution for a co-flow configuration are shown in the form of mean values. It is found that the sub-cooling effect observed in anode - supported cells is almost ameliorated, making the cathode - supported cell favorable from the viewpoint of material stability. In addition, cathode - supported cells are interesting due to the low price of strontium-doped lanthanum manganite (LSM) compared to YSZ. Moreover, they are advantageous when operating on hydrocarbon fuels with low steam-to-carbon ratio since the electrochemical activity of the thin anode prevents it from being poisoned by carbon deposits. Further advantages can be mentioned: the risk of $\mathrm{Ni}$ oxidation by water produced at high current densities is less for thinner anodes, and difficulties associated with volume contraction/expansion resulting from accidental anode redox cycles may be avoided, since the thin anode is not dominating the mechanical integrity of the electrodes - electrolyte membrane. However, the internal methane reforming reaction is impractical for the thin porous anode. If the porous anode is too thin, it will be lacked of hydrogen for electrochemical reaction and lead to the drop of the cell performance. Ho et al. [13] were extended their work shown above [11] by including an analysis of the effects of heat sources on performance of a planar anode - supported solid oxide fuel cell (SOFC). Heat sources in SOFCs are included of ohmic heat losses, heat released by chemical and electrochemical processes and radiation. The analysis took into account the first three types of heat source while neglecting the last type as it is supposed to be comparatively small. The cell with co - flow configuration was working with direct internal reforming of methane. The composite electrodes were discretized allowing the heat source associated with the electrochemical processes to be implemented in a layer of finite thickness. The results show that including ohmic heating in the cell model does have a significant effect on the predicted cell performance and the location of the electrochemical heat source does not affect the cell performance. Recently, Ho et al. [14] developed a numerical three - dimensional model for a planar solid oxide fuel cell (SOFC) with direct internal 
reforming by using Star-CD. The 3D model took into account detailed processes including transport, chemical and electrochemical processes taking place in the cell. The effects of the composite electrode layers were taken into account by considering an electrochemically active layer of finite thickness in each of the electrodes. The numerical results of chemical species, temperature, current density and electric potential distribution were presented. The temperature distribution across the cell was more uniform in the interconnects than in the inner part of the cell, and only tiny differences in the electrical potential between the electrode and the corresponding interconnect were found. The current density in the electrodes was found to be high near the electrolyte and low deep into the electrochemically active layer. The current density was also low under the ribs of the interconnects. Again, their work does not consider the influence of electrode microstructure and operating conditions of the cell performance.

In this study, we developed a mathematical model to predict the cell performance of co - flow planar anode - supported solid oxide fuel cells supplied with natural gas. The effects of chemical and electrochemical reactions on heat and mass transport inside the cell were included in the computational analysis. The concept of optimized partial pre - reforming ratio in the direct internal reforming process of natural gas based on the experimental data of Meusinger et al. [15] was introduced to prevent excessive temperature gradient across the cell. The mass transport in gas flow channels is regarded as mass convection, while mass transport inside porous electrodes is considered as mass diffusion including the effects of species generation from both chemical and electrochemical reactions. The reaction rates of each reaction have been expressed as a function of the temperature from Arhenius' curve fits of the data reported by Lehnert et al [5, 7]. The heat transfer model of convective heat transfer between solid and gas phases as well as conductive heat transfer in solid cell components are included. The endothermic heat consumed during the steam - methane reforming and the exothermic heat released from the electrochemical reactions were included as heat sources in the numerical calculation. This mathematical modeling of a planar anode - supported cell has been 
developed in search for the optimal operating conditions and the optimal geometric cell microstructure. Numerical results will be discussed in order to determine the significant parameters that affect mass transport, thermal behavior and the performance of an anode - supported SOFC.

\section{Mathematical modeling}

\subsection{Model assumptions and cell geometry}

The natural gas was assumed to have the composition of $87 \%$ (by molar) $\mathrm{CH}_{4}, 6 \%$ (by molar) $\mathrm{C}_{2} \mathrm{H}_{6}, 5 \%$ (by molar) $\mathrm{C}_{3} \mathrm{H}_{8}$ and $2 \%$ (by molar) of higher hydrocarbon with $30 \%$ pre - reforming, following the suggestion by Meusinger et al. [15] to introduce the concept of optimized partial pre reforming ratio in the direct internal reforming process of natural gas reported in Table 1 in order to prevent excessive temperature gradient across the cell, $[5,7,15]$. Air supplied to the cathode was used as the oxidant. All gases behave as ideal gases. The electrodes have homogeneous and isotropic structures. Mass transport in the porous electrode is considered as mass diffusion accompanied by chemical and electrochemical reactions. Steam reforming reaction is assumed to occur at the surface of the anode and water - gas shift reaction is assumed to occur inside the void volume of the anode. The electrochemical reaction occurring at the cathode and electrolyte interface forms the oxygen ions that migrate through the ion - conducting electrolyte to the anode and electrolyte interface, where they react with the fuel gases, thus producing water while releasing electrons that flow via an external circuit to the cathode and electrolyte interface. Fully developed gas flowing through channels is considered as incompressible in the laminar flow regime due to its low velocity. Mass transport in gas flow channels are considered mainly as pure mass convection. The simple configuration of a co - flow planar anode - supported solid oxide fuel cell for modeling is shown in Fig 1b. Air and fuel enter the cell in the same direction via the flow channels and diffuse through the porous electrodes (cathode and 
anode). The dimensions of cell components and standard parameters used in calculation are given in Table 2.

\subsection{Mass transport}

Mass transport in a solid oxide fuel cell consists of two kinds: mass diffusion in porous electrodes and mass convection in gas flow channels. Since the cathode is relatively thin compared to the anode, the mass diffusion in the cathode side can be omitted in this computational analysis.

\subsubsection{Mass balance in porous anode}

The gas transport within the anode pores, which is strongly dependent on the anode microstructure, can be described by combining the Stefan - Maxwell and Knudsen diffusion relations. By assuming that the total pressure is uniform throughout the porous anode, the mass diffusive flux through out the anode can be deduced using Eq (1).

$$
\frac{N_{i}}{D_{i, k}^{e f f}}+\sum_{j=1, j \neq i}^{n} \frac{c_{j} N_{i}-c_{i} N_{j}}{D_{i, j}^{e f f}}=-\frac{P}{R T}\left(\frac{d c_{i}}{d y}\right)
$$

where $c_{i}$ is the mole fraction, $P$ is pressure, $T$ is temperature, $y$ is the diffusion direction and $N_{i}$ and $N_{j}$ are the molar flux of species $i$ and $j$, respectively. $D_{i, k}^{\text {eff }}$ is the effective Knudsen diffusion coefficient and $D_{i, j}^{e f f}$ is the effective binary diffusion coefficient.

The effective binary diffusion coefficient $\left(D_{i, j}^{e f f}\right)$ through the porous electrode can be calculated from

$$
D_{i, j}^{e f f}=\psi D_{i, j} \quad \text { or } \quad D_{i, j}^{e f f}=\left(\varepsilon^{1.5}\right) D_{i, j}
$$

All of the binary diffusion coefficient $\left(D_{i, j}\right)$ are calculated according to the Fuller et al.'s expression of the binary diffusion coefficient which referred by Todd et al. [17]. 
The Knudsen diffusion coefficient $\left(D_{i, k}\right)$ and the effective Knudsen diffusion ( $D_{i, k}^{e f f}$ ) coefficient for gas species i can be calculated by Eqs. (3) and (4), respectively [16, 17].

$$
\begin{gathered}
D_{i, k}=\frac{2}{3} \bar{r} \sqrt{\frac{8 R T}{\pi M_{i}}} \\
D_{i, k}^{e f f}=\psi D_{i, k}
\end{gathered}
$$

where $\psi$ is the ratio between porosity and tortuosity $(\varepsilon / \tau)$ and $M_{i}$ is the molecular weight of species $i$.

The steady - state mass balance equation for each component $i$ in the porous anode, where both mass transport and chemical reactions occur, is given by

$$
-\nabla \cdot N_{i}+r_{i}=0
$$

where $r_{i}$ is the molar rate of formation of the species $i$ per unit volume of the porous anode.

Two types of chemical reactions (methane - steam reforming and water - gas shift reactions) occur at the anode while cells are supplied with natural gas.

$$
\begin{aligned}
& \mathrm{CH}_{4}+\mathrm{H}_{2} \mathrm{O} \leftrightarrow \mathrm{CO}+3 \mathrm{H}_{2} \\
& \mathrm{CO}+\mathrm{H}_{2} \mathrm{O} \leftrightarrow \mathrm{CO}_{2}+\mathrm{H}_{2}
\end{aligned}
$$

The endothermic methane steam reforming reaction occurs at the surface of the anode while the exothermic water gas shift reaction occurs in the porous void volume of the anode. The reaction rate of methane - steam reforming reaction and water - gas shift reaction can be determined from Arhenius' curve fits of the data reported by Lehnert et al. [5, 18] as in Eqs. (8) - (11).

$$
\begin{array}{ll}
R_{1}=k_{r f}\left(P_{\mathrm{CH}_{4}} P_{\mathrm{H}_{2} \mathrm{O}}-\frac{\left(P_{\mathrm{H}_{2}}\right)^{3} P_{\mathrm{CO}}}{K_{p r}}\right) & {\left[\mathrm{mol} \cdot \mathrm{m}^{-2} \cdot \mathrm{s}^{-1}\right]} \\
k_{r f}=2395 \exp \left(-\frac{231266}{R T}\right) & {\left[\mathrm{mol} \cdot \mathrm{m}^{-2} \cdot \mathrm{Pa}^{-2} \cdot \mathrm{s}^{-1}\right]}
\end{array}
$$




$$
\begin{array}{ll}
R_{2}=k_{s f}\left(P_{\mathrm{H}_{2} \mathrm{O}} P_{\mathrm{CO}}-\frac{P_{\mathrm{H}_{2}} P_{\mathrm{CO} 2}}{K_{p s}}\right) & {\left[\mathrm{mol} \cdot \mathrm{m}^{-3} \cdot \mathrm{s}^{-1}\right]} \\
k_{s f}=0.0171 \exp \left(-\frac{103191}{R T}\right) & {\left[\mathrm{mol} \cdot \mathrm{m}^{-3} \cdot \mathrm{Pa}^{-2} \cdot \mathrm{s}^{-1}\right]}
\end{array}
$$

where $R_{1}$ is the reaction rate of methane - steam reforming reaction, $R_{2}$ is the reaction rate for water - gas shift reaction, $k_{r f}$ is the forward reaction rate constant of the reforming reaction, and $k_{s f}$ is the forward reaction rate constant of the water - gas shift reaction. The parameter $R$ is the universal gas constant that is equal to $8.314 \mathrm{~J} \cdot \mathrm{mol}^{-1} \cdot \mathrm{K}^{-1} . K_{p r}$ is the equilibrium constant for the steam reforming reaction and $K_{p s}$ is the equilibrium constant for the water - gas shift reaction [18]. Both constants can be calculated from

$$
\begin{gathered}
K_{p r}=1.0267 \times 10^{10} \times \exp \left(-0.2513 Z^{4}+0.3665 Z^{3}+0.5810 Z^{2}-27.134 Z+3.2770\right) \quad \mathrm{Pa}^{2} \\
K_{p s}=\exp \left(-0.2935 Z^{3}+0.6351 Z^{2}+4.1788 Z+0.3169\right) \\
Z=\frac{1000}{T(K)}-1
\end{gathered}
$$

The molar rate of formation of species $i, r_{i}$, in Eq. (5) can be calculated from Eqs. (15) - (19). The minus sign refers to the consumption rate of each species, while the plus sign refers to the production rate.

$$
\begin{array}{ll}
r_{\mathrm{CH}_{4}}=-A_{S} \cdot R_{1} & {\left[\mathrm{~mol} \cdot \mathrm{m}^{-3} \cdot \mathrm{s}^{-1}\right]} \\
r_{\mathrm{H}_{2} \mathrm{O}}=-A_{S} \cdot R_{I}-\varepsilon \cdot R_{2} & {\left[\mathrm{~mol} \cdot \mathrm{m}^{-3} \cdot \mathrm{s}^{-1}\right]} \\
r_{\mathrm{CO}}=A_{S} \cdot R_{I}-\varepsilon \cdot R_{2} & {\left[\mathrm{~mol} \cdot \mathrm{m}^{-3} \cdot \mathrm{s}^{-1}\right]} \\
r_{\mathrm{H}_{2}}=3 \cdot A_{S} \cdot R_{I}+\varepsilon \cdot R_{2} & {\left[\mathrm{~mol} \cdot \mathrm{m}^{-3} \cdot \mathrm{s}^{-1}\right]} \\
r_{\mathrm{CO}_{2}}=\varepsilon \cdot R_{2} & {\left[\mathrm{~mol} \cdot \mathrm{m}^{-3} \cdot \mathrm{s}^{-1}\right]}
\end{array}
$$

The current density from an electrochemical reaction of hydrogen can be calculated by Faraday's law, where 


$$
\begin{aligned}
& N_{H_{2}}=j /(2 \cdot F) \\
& N_{H_{2} O}=-j /(2 \cdot F)
\end{aligned}
$$

\subsubsection{Mass balance in gas flow channels}

The mole fraction of each gas species changes along the longitudinal direction of flow channels due to the normal molar diffusive flux $N_{i}$ in $y$ direction through the porous electrodes. For steady state, mass balance for each species $i$ can be deduced as in Eq. (22). Note that the pressure drop along the flow channels is assumed negligible.

$$
\frac{d F_{i}}{d x}=2 \pi X v_{i} N_{i(y=0)}
$$

where $F_{i}$ is the molar flow rate for species $i$ and $v_{i}$ is the stoichiometric coefficient ( 1 for reactant species and +1 for product species).

\subsection{Heat transfer and temperature distribution within the cell}

The heat transfer in the porous electrodes and dense electrolyte is dominated by conduction.

$$
\lambda_{\text {eff }}\left(\nabla^{2} T\right)+q=0
$$

where $q$ is related to energy source terms reflecting both the exothermic and endothermic reactions. The effective thermal conductivity coefficient $\left(\lambda_{\text {eff }}\right)$ consists of a solid conductive coefficient $\left(\lambda_{s}\right)$ and a gas conductive coefficient $\left(\lambda_{f}\right)$.

$$
\lambda_{e f f}=\varepsilon \lambda_{f}+(1-\varepsilon) \lambda_{s}
$$

Heat convection within the porous media is assumed to be negligible in comparison with thermal conduction. The heat generation related to the chemical reactions within the porous anode is expressed by the reaction rate as :

$$
q_{i}=R_{i}\left(-\Delta H_{i}^{0}\right) \quad i=1,2 \text { and } \quad q=q_{1}+q_{2}
$$




$$
\begin{aligned}
& q_{1}=A_{S}\left(R_{1}\left(-\Delta H_{1}^{o}\right)\right) \\
& q_{2}=\varepsilon\left(R_{2}\left(-\Delta H_{2}^{o}\right)\right)
\end{aligned}
$$

where $q_{1}$ is the heat consumed during the methane - steam reforming at the surface of anode, $q_{2}$ is the heat released during the water-gas shift reaction in the void volume of anode, $\Delta H_{1}^{O}$ is the enthalpy resulting from methane - steam reforming reaction that is equal to $242,000 \mathrm{~J} \mathrm{~mol}^{-1}$ at $800{ }^{\circ} \mathrm{C}$ and $\Delta H_{2}^{0}$ is the enthalpy resulting from the water-gas shift reaction that is equal to $-38,600 \mathrm{~J} \mathrm{~mol}^{-1}$ at $800{ }^{\circ} \mathrm{C}$. $\mathrm{A}_{\mathrm{S}}$ is the specific surface area (area per volume ratio) and $\varepsilon$ is the porosity of the anode.

The heat generation rate $\left(q_{3}\right)$ due to the electrochemical process at the electrode/electrolyte interface is expressed as follow,

$$
q_{3}(x)=\frac{j(x)}{2 F} \Delta H_{H_{2} O}+j(x) \cdot V_{C}
$$

Heat transfer at the interface between the gas flow channels and the electrode is pure convection, where

$$
q_{\text {conv }, i}=h_{i}\left(T_{i}-\bar{T}_{C, i}\right)
$$

and $h_{i}$ is the convective heat transfer coefficient of species $i$. The heat transfer coefficients are computed from the Nusselt numbers and strongly depend on the geometry of the gas channels, gas properties, and flow characteristics. In this analysis, laminar flow is assumed in the gas flow channels. The length per hydraulic diameter $\mathrm{L} / \mathrm{D}_{\mathrm{H}}$ is greater than 10 to ensure the fully developed flow regime. The well - known heat transfer correlation proposed by Sieder and Tate [24] is used and the heat transfer coefficients are estimated to be, respectively, around 49 and $57 \mathrm{~W} \mathrm{~m}^{-2} \mathrm{~K}^{-1}$ for the cathodic and anodic sides. The temperature term $\bar{T}_{C, i}$ is the average temperature along the flow channels. The temperature $T_{i}$ is the surface temperature of the electrode. 
The temperature gradient across the cell electrode is calculated by combining Eq. (23) and Eqs. (24) - (27) with the boundary conditions in Eqs. (28) and (29). The temperature distribution will be used to determine the chemical kinetic constants according to Arrhenius' law. The iterative calculation is performed and repeated until convergence of both gas concentration and temperature distributions can be achieved.

\subsection{Cell electrical performance}

The cell voltage $V_{C}$ is assumed constant along the cell length and can be calculated by potential balance,

$$
V_{C}=E_{j=0}-\left(\eta_{\text {ohmic }}+\eta_{\text {conc }, a}+\eta_{\text {conc }, c}+\eta_{\text {act }, a}+\eta_{\text {act }, c}\right)
$$

where $E_{j=0}$ is the open circuit voltage that can be approximated from Nernst's equation.

$$
E=-\frac{\Delta G^{o}}{2 F}-\frac{R T}{2 F} \ln \left(\frac{p_{H_{2} O}^{a}}{p_{H_{2}}^{a}\left(p_{O_{2}}^{c}\right)^{l / 2}}\right)=E^{o}+\frac{R T}{4 F} \ln \left(\frac{p_{O_{2}}^{c}\left(p_{H_{2}}^{a}\right)^{2}}{\left(p_{H_{2} O}^{a}\right)^{2}}\right)
$$

where $\Delta G^{o}$ is the net standard Gibbs free energy of electrochemical reaction at 1 atm and $25^{\circ} \mathrm{C}, E^{o}$ is the standard Nernst potential at 1 atm and $25^{\circ} \mathrm{C}, P_{\mathrm{H}_{2} \mathrm{O}}^{a}$ is the water partial pressure, $P_{\mathrm{H}_{2}}^{a}$ is the hydrogen partial pressure, and $P_{O_{2}}^{C}$ is the oxygen partial pressure.

The parameter $\eta_{\text {ohmic }}$ is ohmic overpotential. In SOFCs, ohmic overpotential in the anode and the cathode are assumed to be negligible, hence the ohmic overpotential is only related to the electrolyte resistance. $\eta_{\text {conc }}$ is the concentration overpotential and $\eta_{a c t}$ is the activation overpotential. Therefore the ohmic overpotential based on the electrolyte resistance can be determined from Eq. (32).

$$
\eta_{\text {ohmic }}=j\left(A S R_{\text {ohmic }}\right)=j \cdot\left(\frac{t_{e}}{\sigma}\right)
$$

where $t_{e}$ is the thickness of the electrolyte. The electrolyte conductivity $(\sigma)$ can be calculated from 


$$
\sigma=\frac{A \cdot\left(e^{-\Delta G_{a c t} /(R T)}\right)}{T}
$$

where $A$ is the electrolyte constant and $\Delta G_{a c t}$ is the electrolyte activation energy.

In the case of SOFCs with thick anodes, the anodic concentration or anodic diffusive overpotential can be expressed from Nernst's equation,

$$
\eta_{\text {conc }, a}=\frac{R T}{2 F} \ln \left(\frac{c_{\mathrm{H}_{2}} c_{\mathrm{H}_{2} \mathrm{O}}^{o}}{c_{\mathrm{H}_{2}}^{o} c_{\mathrm{H}_{2} \mathrm{O}}}\right)
$$

where $c_{i}$ and $c_{i}^{0}$ represent the mole fractions at nonzero and zero current densities at the anodeelectrolyte interface. The cathodic concentration overpotential is expressed as

$$
\eta_{\text {conc }, c}=\frac{R T}{2 F} \ln \left(1-\frac{j}{j_{\text {lim }, c}}\right)
$$

where $j_{\text {lim,c }}$ is the cathode limiting current density.

The activation overpotential terms are related to the electrochemical reaction rate. The activation overpotential terms located at the electrode - electrolyte interface can be calculated from the Butler - Volmer equation. The anodic and cathodic activation overpotential losses are expressed respectively as

$$
\begin{aligned}
\eta_{a c t, a} & =\frac{R T}{F} \operatorname{arcsinh}\left(\frac{j}{2 \cdot j_{0, a}}\right) \\
\eta_{a c t, c} & =\frac{R T}{F} \operatorname{arcsinh}\left(\frac{j}{2 \cdot j_{0, c}}\right)
\end{aligned}
$$

where $j_{0, a}$ and $j_{0, c}$ are respectively the anodic and cathodic current densities at which the overvoltage begins to move from zero. 


\subsection{Mathematical model algorithm}

The Runge - Kutta method was used to solve mass diffusion equations coupled with the heat transfer equations. The molar fraction of species $i$ at $c_{i}(x, y=0)$ is equal to the molar fraction in the gas flow channels. At the position where $y$ equal to the anode thickness $t_{a n}$, the mass flux $N_{i}$ is zero for $\mathrm{CH}_{4}, \mathrm{CO}$ and $\mathrm{CO}_{2}$, while $N_{i}$ is given by the Faraday's law Eqs. (20) - (21) respectively for $\mathrm{H}_{2}$ and $\mathrm{H}_{2} \mathrm{O}$. The numerical iteration is repeated until the predicted current density agrees with the corresponding current density of the specified cell voltage $\left(V_{C}\right)$ in Eq (30).

\section{Model validation}

The literature lacks experimental data on direct internal reforming solid oxide fuel cells (DIRSOFCs) supplied with natural gas or methane fuel. Information on input parameters for experimentation is also lacking. In the literature presented by Jiang Liu and Scott A. Barnett, predicted cell performance is compared with experimental data [22] and results are shown in Figure 2. This validation calculation uses the parameters specified in Table 3 as appeared in the previous experimental setup. Additional parameters are the standard parameters listed in Table 2. The performance of the cell is considered, when the cell is supplied with natural gas with $30 \%$ pre reformed and with the composition as shown in Table 1. Oxygen composition in the ambient air is used as an oxidant, operating at pressures and temperatures of 1 atm and $800{ }^{\circ} \mathrm{C}$. The Fluent simulation result by V. M. Janardhanan et al. [23] is also included for comparison proposes in Figs. 2 and 3. The present simulation results agree in acceptable manner with the experimental results as seen in Figs. 2 and 3. However, the major discrepancy between the present predicted results and the experimentally observed data is at the open circuit voltage (OCV). Jiang Liu's experimental data show maximum $\mathrm{OCV}$ of $1.17 \mathrm{~V}$ at $800^{\circ} \mathrm{C}$, while, the present model predicts a much higher OCV of $1.23 \mathrm{~V}$ at $800^{\circ} \mathrm{C}$. In Fig.3, the difference between the present results and the experimental data given by Jiang Liu et al. is in the error range of about $0.01-5 \%$. Maximum percentage error occurs at OCV and 
minimum error occurs at current density of $0.5 \mathrm{~A} . \mathrm{cm}^{-2}$ as shown in Fig. 3. The difference is mainly due to some assumptions and conditions considered in the present study that are not available in the experimental literature.

\section{Results and discussion}

The developed model can be used to investigate the effects of operating conditions and design parameters, especially the geometry of electrode microstructure on the performance of a co-flow planar anode supported SOFC. First, simulations have been performed on the basis of standard physical parameters of standard cell properties and its geometry shown in Table 2. Operating conditions have been set to $0.7 \mathrm{~V}$ for the cell potential, $800^{\circ} \mathrm{C}$ for the gas temperature in the complete cell, $1 \mathrm{~atm}$ for the gas - phase pressure, $100 \mathrm{~mL} \cdot \mathrm{min}^{-1}$ for both the anodic reactant (composition following Table 1 at $S / C=1$ ) and the cathodic (with $21 \% \mathrm{O}_{2}$ ) flow rates. According to literature [8], an $\mathrm{S} / \mathrm{C}$ ratio equal to 1 allows the avoidance of carbon deposition at $800^{\circ} \mathrm{C}$. Nevertheless, a $S / C$ ratio lower than 1 could occur locally within the thick anode leading to carbon deposition.

In Fig. 4, the calculated values of the gas mole fraction are given corresponding to the cell length $(x)$ and the anode thickness $(y)$. These mole fraction profiles are plotted in the same unit scale in order to allow meaningful comparison. As expected, the steam reforming reaction of $\mathrm{CH}_{4}$ is predicted to occur largely within the electrode volume close to the gas inlet leading to increase in the hydrogen mole fraction $\left(\mathrm{H}_{2}\right)$ and decrease of $\mathrm{CH}_{4}$. The slightly decrease of $\mathrm{CO}$ mole fraction refers to the comparatively lower production rate of $\mathrm{CO}$ from the steam reforming reaction than the consumption rate of $\mathrm{CO}$ as the reactant of the water gas shift reaction. The $\mathrm{CO}_{2}$ is created from the low production rate of the water gas shift reaction. $\mathrm{H}_{2} \mathrm{O}$ mole fraction presents at the lower amount near the gas inlet and $\mathrm{H}_{2} \mathrm{O}$ mole fraction increases along the direction of anode length due to the reaction product of $\mathrm{H}_{2}$ electrochemical oxidation at the interface. Figure 5 presents the calculated mole fraction of $\mathrm{O}_{2}$ along the cell length $(x)$ and the cathode thickness $(y)$. Since the cathode is 
relatively thin compared to the anode, the mass diffusion in the cathode side can be omitted in this computational analysis and the thermal analysis is also omitted. The $\mathrm{O}_{2}$ mole fraction is low near the interface due to the consumption of electrochemical reaction.

The resulting temperature distribution throughout the anode is shown in Fig.6. Figures 6a, 6b and $6 \mathrm{c}$ are the results for the gas temperature of $800{ }^{\circ} \mathrm{C}, 700{ }^{\circ} \mathrm{C}$ and $650{ }^{\circ} \mathrm{C}$ in corresponding to the cell operating condition of $0.7 \mathrm{~V}, 0.8 \mathrm{~V}$ and $0.9 \mathrm{~V}$, respectively. Note that the temperature increases and reaches the highest level at the anode/electrolyte interface.

Effects of individual parameter on cell performance are further studied. The effect of operating temperature on the cell's current density and voltage is shown in Fig. 7. The effect of temperature on the cell power density and voltage is shown in Fig. 8, for the operating pressure of $1 \mathrm{~atm}$.

Figure 7 shows that, at zero current density, the open circuit voltage decreases as temperature increases, whereas when the current density increases, the cell voltage increases with the operating temperature of the cell. Increase in operating temperature not only enhances the rate of electrochemical reaction, but also increases the rate of ionic conductivity, which in turn minimizing the ohmic contribution to the cell overpotential and thus enhancing the cell voltage and cell power density as shown in Figs. 7 and 8 respectively. The mathematical model predicted that the maximum power density of the cell, about $0.28 \mathrm{~W} . \mathrm{cm}^{-2}$, is given at current density of $0.38 \mathrm{~A} . \mathrm{cm}^{-2}$ and cell voltage of 0.73 volt when the cell is operated at the standard pressure of 1 atm and temperature of 800 ${ }^{\circ} \mathrm{C}$, with the fuel utilization of $48 \%$.

Figures 9 and 10 show the effects of operating pressure on the cell voltage and on power density at the specified current density, respectively. Both cell voltage and power density increase with the operating pressure due to the increase in reactant concentration. It can be observed that increasing the pressure not only increases the open circuit voltage but also increases the actual cell voltage. With the increase of pressure, the reactant concentration at the reaction sites increases. This 
in turn enhances the rate of electrochemical reaction and rate of mass transport, resulting in the minimization of anode and cathode overpotentials and hence producing better performance. However, increasing the operating pressure results in other problems such as limitations on material selection, gas sealing, and mechanical strength of the planar SOFC cell components [1].

In order to study the effects of cell geometry such as porosity, tortuosity, pore size, and electrolyte thickness on cell performance, the operating condition is set at $800^{\circ} \mathrm{C}$ and $1 \mathrm{~atm}$. The effects of porosity on cell voltage and on power density at the specified current density are shown in Figs. 11 and 12, respectively. The cell voltage and power density only decrease with the porosity at high current density. Increasing the porosity of the cell components decreases the cell performance. Increasing the porosity increases the void fraction and decreases the solid fraction of the porous medium resulting in the reduction of the active surface area available for the electrochemical reaction. Moreover, the effective ionic and electron conductivities of the porous decrease with the increase of porosity, which results in the increase of ohmic overpotential. Although the concentration overpotential decreases with the increase of porosity due to the increased mass transport rates; the cell voltage and power density decreases due to increasing of ohmic overpotential with porosity.

The effects of tortuosity on the cell performance are reported in Figs. 13 and 14. Increasing the tortuosity of the porous medium decreases the performance of the cell. Increasing the tortuosity of the porous medium means that increasing the length of tortuous flow paths, which leads to additional resistance to the reactant species diffusing through the porous medium, thus resulting in the reduction of reactant concentration at the reaction sites and thereby decreasing the rate of electrochemical reaction. In addition, the effective ionic and electronic conductivities decrease with the increase of tortuosity, resulting in the increase of ohmic overpotential, and hence decreasing cell voltage and power density.

The effects of the pore size on single cell performance are shown in Figs. 15 and 16. The 
overall diffusion in the porous electrodes was based on a combination of both Knudsen diffusion and molecular diffusion. The diffusion process within a pore can be typically divided into two diffusion mechanisms: molecular diffusion and Knudsen diffusion. Molecular diffusion is dominant for large pore sizes and high system pressure, while Knudsen diffusion becomes significant when the mean-free path of the molecular species is much larger than the pore size. Increasing pore size could facilitate the Knudsen diffusion process, thus resulting in decreasing of concentration overpotential. Progressively, molecular diffusion became dominating over Knudsen diffusion for large pore size. Therefore, the concentration overpotential became less sensitive to pore size variation if the pore size was sufficiently high. As the length of the three phase boundary (TPB) was the resultant of the connectivity of the catalyst and YSZ (yttria stabilized zirconia) particles, its value was determined by the pore size, porosity, grain size and the overlap of particles. Therefore, the activation overpotential could be minimized by adjusting the pore size to a certain value since the exchange current density was proportional to the length of the TPB. As a result, an optimal pore size of $3 \mu \mathrm{m}$ was found to achieve the best cell performance in terms of cell voltage (as in Fig. 15) and power density (as in Fig. 16).

Figures 17 and 18 show the effects of electrolyte thickness on cell performance. The cell voltage and power density at a specified current density increase as the electrolyte thickness decreases due to the decrease of ohmic loss.

\section{Conclusion}

A mathematical model for predicting the performance of a co - flow planar anode supported solid oxide fuel cell with internal reforming of natural gas has been developed. The model simultaneously solved mass and energy transport equations as well as chemical and electrochemical reactions. The model can effectively predict the compound species distributions, temperature profiles 
as well as the cell performance at various operating conditions. The model is useful in analyzing the effects of electrode microstructure parameters, such as porosity, tortuosity and pore size, as well as electrolyte thickness on cell performance. The performance of the cell was reported in terms of cell voltage and power density at specified current densities for several operating temperatures and pressures. Regarding the temperature effect, as the operating temperature increases, the concentration overpotential will increase, while both the ohmic and activation overpotentials will decrease drastically. The overall effect will be a significant increase in cell voltage and power density. Moreover, the cell voltage and power density can be increased by increasing the operating pressure to reduce both the concentration and activation overpotentials. The simulation results show that the steady state performance is almost insensitive to microstructure of cells such as porosity and tortuosity unlike the operating pressure and temperature. The power output could be maximized by adjusting the pore size to an optimal value, similarly to porosity and tortuosity. At standard operating pressure (1 atm) and $800^{\circ} \mathrm{C}$ with $48 \%$ fuel utilization, an output cell voltage of 0.73 volt, a current density of 0.38 A.cm ${ }^{-2}$ with a power density of $0.28 \mathrm{~W} . \mathrm{cm}^{-2}$ was predicted. The model - predicted results are validated with the experimental data found in the literature. A good agreement is obtained between the predicted values and the measured data.

\section{Acknowledgement}

Authors would like to acknowledge with gratitude the financial support from the National Research University Fund, the Thailand Higher Education Commission Fund and the Thailand Research Fund. 


\section{Appendices}

\section{Appendix A: Specific surface area or reactive surface area per unit volume of the electrode $\left(A_{S}\right)$}

The term $A_{S}\left(\mathrm{~m}^{2} \mathrm{~m}^{-3}\right.$ or $\left.\mathrm{m}^{-1}\right)$ can be calculated with the equation in the literature [25], given as

$$
A_{S}=\pi \sin ^{2} \theta r_{e l}^{2} n_{t} n_{e l} n_{i o} \frac{Z_{e l} Z_{i o}}{Z} p_{e l} p_{i o}
$$

where $\theta$ is the contact angle between electron and ion conducting particles that is equal to $15^{\circ}, r_{e l}$ is the radius of the electron conducting particles that is equal to $1.0 \mu \mathrm{m} ., n_{t}$ is the total number of particles per unit volume, $n_{e l}$ and $n_{i o}$ are the number fraction of electron and ion conducting particles, $Z_{e l}$ and $Z_{i o}$ are the coordination number of electron and ion conducting particles. $Z$ is the total average particle coordination number in the electrode which is equal to 6 and $p_{e l}$ and $p_{i o}$ are the probabilities for an electron and an ion conducting particle to belong to connecting ends of the composite. All previous mentioned parameters required to calculate $A_{S}$ which are related to each other as shown here,

$$
\begin{aligned}
& n_{e l}=\frac{\varphi}{\left[\varphi+\left((1-\varphi) /\left(r_{i o} / r_{e l}\right)^{3}\right)\right]} \quad \text { and } \quad n_{i o}=1-n_{e l} \\
& Z_{e l}=3+\frac{Z-3}{\left[n_{e l}+\left(1-n_{e l}\right)\left(r_{i o} / r_{e l}\right)^{2}\right]} \quad \text { and } \quad Z_{i o}=3+\frac{(Z-3)\left(r_{i o} / r_{e l}\right)^{2}}{\left[n_{e l}+\left(1-n_{e l}\right)\left(r_{i o} / r_{e l}\right)^{2}\right]} \\
& p_{e l}=\left[1-\left(4-Z_{e l-e l}\right)^{2.5}\right]^{0.4} \text { and } \quad p_{i o}=\left[1-\left(4-Z_{i o-i o}\right)^{2.5}\right]^{0.4}
\end{aligned}
$$

where $\varphi$ is a volume fraction of the electron conducing particle in an electrode, which is equal to 0.5 , $Z_{e l-e l}$ represents the average coordination number between electronic particles and $Z_{i o-i o}$ represents the average coordination number between ionic particles,

$$
Z_{e l-e l}=\frac{n_{e l} Z_{e l}^{2}}{Z} \quad \text { and } \quad Z_{i o-i o}=\frac{n_{i o} Z_{i o}^{2}}{Z}
$$

The total number of particles per unit volume $\left(n_{t}\right)$, can be determined according to Eq. (43), 


$$
n_{t}=\frac{1-\varepsilon}{(4 / 3) \pi r_{e l}^{3}\left[n_{e l}+\left(1-n_{e l}\right)\left(r_{i o} / r_{e l}\right)^{3}\right]}
$$

\section{References}

[1] S.C. Singhal, K. Kendall, High Temperature Solid Oxide Fuel Cells: Fundamentals Design and Applications, Elsevier, Oxford, 2003.

[2] J. Larminie, A. Dicks, Fuel Cell Systems Explained, John Wiley and Sons, Chichester, 2003.

[3] P. Aguiar, C.S. Adjiman, N.P. Brandon, Anode - Supported Intermediate Temperature Direct Internal Reforming Solid Oxide Fuel Cell I: model based steady-state. Journal of Power Sources. 138 (2004) 120 - 136.

[4] H. Yakabe, M. Hishinuma, M. Uratani, Y. Matsuzaki, I. Yasuda, Evaluation and Modeling of Performance of Anode - Supported Solid Oxide Fuel Cell. Journal of Power Sources. 86 (2000) $423-431$.

[5] W. Lehnert, J. Meusinger, F. Thom, Modeling of Gas Transport Phenomena in SOFC Anodes. Journal of Power Sources. 87 (2000) 57 - 63.

[6] R. Suwanwarangkul, E. Croiset, M.W. Fowler, P.L. Douglas, E. Entchev, M.A. Douglas, Performance Comparison of Fick's, Dusty-gas and Stafan-Maxwell Models to Predict the Concentration Overpotential of a SOFC Anode. Journal of Power Sources. 122 (2003) 9-18.

[7] T. Ackmann, L. G. J. De Haart, W. Lehnert, D. Stolten, Modeling of Mass and Heat Transport in Planar substrate Type SOFCs. Journal of the Electrochemical Society 150(6) (2003) A783 - A789.

[8] B. Morel, J. Laurencin, Y. Bultel, F. Lefebvre-Joud, Anode-Supported SOFC Model Centered on the Direct Internal Reforming. Journal of the Electrochemical Society 152(7) (2005) A1382 - A1389. 
[9] K. Nikooyeh, A.A. Jeje, J.A., Hill, 3D Modeling of Anode - Supported Planar SOFC with Internal Reforming of Methane. Journal of Power Sources. 171(2) (2007) 601-609.

[10] A. Pramuanjaroenkij, S. Kakac, X.Y. Zhou, Mathematical Analysis of Planar Solid Oxide Fuel Cells. International Journal of Hydrogen Energy. 33(10) (2008) 2547-2565.

[11] T.X. Ho, P. Kosinski, A. C. Hoffmann. A. Vik, Numerical Analysis of a Planar Anode Supported SOFC with Composite Electrodes, International Journal of Hydrogen Energy. 34 (2009) 3488 - 3499 .

[12] T.X. Ho, P. Kosinski, A. C. Hoffmann. A. Vik, Modeling of Transport, Chemical and Electrochemical Phenomena in a Cathode - Supported SOFC, Chemical Engineering Science. 64 (2009) $3000-3009$.

[13] T.X. Ho, P. Kosinski, A. C. Hoffmann. A. Vik, Effects of Heat Sources on the Performance of a Planar Solid Oxide Fuel Cell, International Journal of Hydrogen Energy. 35 (2010) $4276-4284$.

[14] T.X. Ho, P. Kosinski, A. C. Hoffmann. A. Vik, Transport, Chemical and Electrochemical Processes in a Planar SOFC: Detailed Three - Dimensional Modeling, Journal of Power Sources. 195 (2010) $6764-6773$.

[15] J. Meusinger, E. Riensche, U. Stimming, Reforming of Natural Gas in Solid Oxide Fuel Cell Systems. Journal of Power Sources. 71 (1998) 315 - 320.

[16] R.B. Bird, W.E. Stewart, E.N. Lightfoot, Transport Phenomena. Second edition, John Wiley and Sons, New York, U.S.A. (2001).

[17] B. Tod, J.B. Young, Thermodynamics and Transport Properties of Gases for Use in Solid Oxide Fuel Cell Modeling. Journal of Power Sources. 110 (2002) 186 - 200. 
[18] B.A. Haberman, J.B. Young, Three Dimensional Simulation of Chemically Reacting Gas Flows in the Porous Support Structure of an Integrated Planar Solid Oxide Fuel Cell. International Journal of Heat and Mass Transfer. 47 (2004) 3617 - 3629.

[19] R. O’Hayre, S. Won Cha, W. Colella, F.B. Prinz, Fuel Cell Fundamentals. John Wiley and Sons New York U.S.A. (2006).

[20] M.M. Hussain, X. Li, I. Dincer, Mathematical Modeling of Planar Solid Oxide Fuel Cells. Journal of Power Sources. 161 (2006) 1012 - 1022.

[21] M.A. Khaleel, Z. Lin, P. Singh, W. Surdoval, D. Collin, A Finite Element Analysis Modeling Tool for Solid Oxide Fuel Cell Development: Coupled Electrochemistry Thermal and Flow Analysis in MARC. Journal of Power Sources. 130 (2004) 136 - 148.

[22] J. Liu, Scott A. Barnett, Operation of Anode-supported Solid Oxide Fuel Cells on Methane and Natural gas. Journal of Solid State Ionics. 158 (2003) 11 - 16.

[23] V. M. Janardhanan, O. Deutschmann, CFD Analysis of a Solid Oxide Fuel Cell with Internal reforming: Coupled interactions of Transport, Heterogeneous Catalysis and Electrochemical Processes. Journal of Power Sources. 162 (2006) 1192 - 1202.

[24] N. P. Cheremisinoff, Handbook of Heat and Mass Transfer, Editor, GPC, 1986, 895.

[25] P. Costamagna, P. Costa, V. Antonucci, Micro - Modeling of Solid Oxide Fuel Cell Electrodes. Electrochimica Acta. 43(1998) 375-394.

\section{Nomenclatures}

$A_{S} \quad$ Reactive surface area per unit volume $\left[\mathrm{m}^{2} \cdot \mathrm{m}^{-3}\right]$

$c_{i} \quad$ Molar fraction of species i $\left[\mathrm{mol} . \mathrm{mol}^{-1}\right]$

$D_{i, j} \quad$ Binary diffusion coefficient of the species i $\left[\mathrm{m}^{2} \cdot \mathrm{s}^{-1}\right]$

$D_{i, k} \quad$ Knudsen diffusion coefficient of the species i $\left[\mathrm{m}^{2} \cdot \mathrm{s}^{-1}\right]$

$E_{j=0} \quad$ Open circuit voltage [Volt] 
$F \quad$ Faraday constant $96485\left[\mathrm{C} \cdot \mathrm{mol}^{-1}\right]$

$F_{i} \quad$ Molar flow rate of fuel in channel [mol.s $\left.{ }^{-1}\right]$

$j \quad$ Current density $\left[\right.$ A. $\left.\mathrm{m}^{-2}\right]$

$j_{0} \quad$ Exchange current density $\left[\right.$ A.m $\left.{ }^{-2}\right]$

$j_{\text {lim }} \quad$ Limiting current density $\left[\right.$ A.m $\left.{ }^{-2}\right]$

$k_{r f} \quad$ Forward reaction rate constant of the reforming reaction $\left[\mathrm{mol} \cdot \mathrm{m}^{-2} \cdot \mathrm{Pa}^{-2} \cdot \mathrm{s}^{-1}\right.$ ]

$k_{s f} \quad$ Forward reaction rate constant of the water - gas shift reaction $\left[\mathrm{mol} \cdot \mathrm{m}^{-3} \cdot \mathrm{Pa}^{-2} \cdot \mathrm{s}^{-1}\right.$ ]

$K_{p r} \quad$ Equilibrium constant for the steam reforming reaction $\left[\mathrm{Pa}^{2}\right]$

$K_{p s} \quad$ Equilibrium constant for the water-gas shift reaction

L $\quad$ Length $[\mathrm{m}]$

$M \quad$ Molecular weight $\left[\mathrm{kg} \cdot \mathrm{kmol}^{-1}\right]$

$N \quad$ Molar flux $\left[\mathrm{mol} \cdot \mathrm{m}^{-2} \cdot \mathrm{s}^{-1}\right]$

$P \quad$ Operating pressure [atm]

$q \quad$ Heat source $\left[\mathrm{W} . \mathrm{m}^{-3}\right]$

$R \quad$ Gas constant, $8.314\left[\mathrm{~J} \cdot \mathrm{mol}^{-1} \cdot \mathrm{K}^{-1}\right]$

$\bar{r} \quad$ Mean value of the pore radii $[\mathrm{m}]$

$r_{i} \quad$ Molar rate of formation of species i per unit volume $\left[\mathrm{mol} . \mathrm{m}^{-3} . \mathrm{s}^{-1}\right]$

$T \quad$ Operating temperature $[\mathrm{K}]$

$t \quad$ Thickness [m]

$U_{f} \quad$ Fuel utilization [\%]

$V_{C} \quad$ Cell voltage [Volt]

$\Delta H \quad$ Enthalpy change of reaction $\left[\mathrm{J}^{\mathrm{m}} \mathrm{mol}^{-1}\right]$

$\varepsilon \quad$ Porosity

$\lambda \quad$ Thermal conductivity coefficient $\left[\mathrm{W} \cdot \mathrm{m}^{-1} \cdot \mathrm{K}^{-1}\right]$ 
$\sigma \quad$ Conductivity $\left[\mathrm{S}^{-\mathrm{m}^{-1}}\right]$

$\eta_{\text {act }}$ Activation overpotential [Volt]

$\eta_{\text {conc }}$ Concentration overpotential [Volt]

$\eta_{\text {ohmic }}$ Ohmic overpotential [Volt]

$v \quad$ Stoichiometric coefficient

$\rho \quad$ Gas density $\left[\mathrm{kg} \cdot \mathrm{m}^{-3}\right]$

$\tau \quad$ Tortuosity

$\alpha \quad$ Charge transfer coefficient

$\psi \quad$ Porosity to tortuosity ratio of electrode $[\varepsilon / \tau]$

\section{Subscripts}

$\begin{array}{ll}\text { an } & \text { Anode } \\ \text { cat } & \text { Cathode } \\ e & \text { Electrolyte } \\ \text { eff } & \text { Effective } \\ f & \text { Fuel channel } \\ i & \text { Species i }\end{array}$

\section{Table Captions}

Table 1 Fuel composition after $30 \%$ pre-reforming of natural gas supplied to the anode $[5,7,15]$

Table 2 Standard parameters used in this study

Table 3 Standard parameters used for model validation 


\section{Figure Captions}

Figure 1. A schematic model of a planar anode-supported solid oxide fuel cell (a) Stack schematic (b) 1 cell schematic used in the modeling

Figure 2. Voltage against current density comparison with literature experiment data [J. Liu et al. 22]

Figure 3. Present model percentage error comparison with literature experiment data [J. Liu et al. 22]

Figure 4. Simulated two - dimensional anode gas mole fraction of (a) $\mathrm{CH}_{4}$ (b) $\mathrm{CO}_{2}$, (c) $\mathrm{CO}$, (d) $\mathrm{H}_{2}$ and (e) $\mathrm{H}_{2} \mathrm{O}$ with standard parameters $\left(0.7 \mathrm{~V}, 800^{\circ} \mathrm{C}\right.$ and 1 atm.)

Figure 5. Simulated two - dimensional cathode gas mole fraction of $\mathrm{O}_{2}$ with standard parameters $\left(0.7 \mathrm{~V}, 800^{\circ} \mathrm{C}\right.$ and $\left.1 \mathrm{~atm}.\right)$

Figure 6. Simulated two - dimensional anode material temperature profile with standard parameters (a) $0.7 \mathrm{~V}, 800^{\circ} \mathrm{C}$ and 1 atm. (b) $0.8 \mathrm{~V}, 700{ }^{\circ} \mathrm{C}$ and 1 atm. and (c) $0.9 \mathrm{~V}, 650^{\circ} \mathrm{C}$ and 1 atm.

Figure 7. Effect of temperature on cell voltage and current density

Figure 8. Effect of temperature on cell power density and current density

Figure 9. Effect of pressure on cell voltage

Figure 10. Effect of pressure on cell power density

Figure 11. Effect of porosity on cell voltage

Figure 12. Effect of porosity on cell power density

Figure 13. Effect of tortuosity on cell voltage

Figure 14. Effect of tortuosity on cell power density

Figure 15. Effect of pore size on cell voltage

Figure 16. Effect of pore size on cell power density

Figure 17. Effect of electrolyte thickness on cell voltage

Figure 18. Effect of electrolyte thickness on cell power density 


\begin{tabular}{|llllll|}
\hline Component & $\mathrm{CH}_{4}$ & $\mathrm{CO}$ & $\mathrm{H}_{2} \mathrm{O}$ & $\mathrm{H}_{2}$ & $\mathrm{CO}_{2}$ \\
\hline Molar fraction $\left(c_{i}\right)$ & 0.171 & 0.029 & 0.493 & 0.263 & 0.044 \\
\hline
\end{tabular}

Table 2

\begin{tabular}{|c|c|}
\hline \multicolumn{2}{|c|}{ Geometrical parameters of the cell } \\
\hline Anode thickness $\left(t_{a n}\right)$ & $2 \mathrm{~mm}$ \\
\hline Anode length $\left(L_{a n}\right)$ & $20 \mathrm{~mm}$ \\
\hline Anode porosity $\left(\varepsilon_{a n}\right)$ & $0.375[20]$ \\
\hline Anode tortuosity $\left(\tau_{a n}\right)$ & $2.75[20]$ \\
\hline Anode pore radius $\left(r_{a n}\right)$ & $0.75 \mu \mathrm{m}[20]$ \\
\hline Cathode thickness $\left(t_{c a t}\right)$ & $60 \mu \mathrm{m}$ \\
\hline Cathode length $\left(L_{c a t}\right)$ & $20 \mathrm{~mm}$ \\
\hline Cathode porosity $\left(\varepsilon_{\text {cat }}\right)$ & $0.375[20]$ \\
\hline Cathode tortuosity $\left(\tau_{c a t}\right)$ & $2.75[20]$ \\
\hline Cathode pore radius $\left(r_{c a t}\right)$ & $0.75 \mu \mathrm{m}[20]$ \\
\hline Electrolyte thickness $\left(t_{e}\right)$ & $60 \mu \mathrm{m}$ \\
\hline Electrolyte length $\left(L_{e}\right)$ & $20 \mathrm{~mm}$ \\
\hline \multicolumn{2}{|c|}{ Chemical and electrochemical parameters } \\
\hline Transfer coefficient $(\alpha)$ & $0.5[19]$ \\
\hline Cathode exchange current density $\left(j_{o c}\right)$ & $0.1 \times 10^{4}$ A.m $^{-2}[19]$ \\
\hline Anode exchange current density $\left(j_{o a}\right)$ & $1 \times 10^{4}$ A.m ${ }^{-2}[8]$ \\
\hline Cathode limiting current density $\left(j_{\text {lim }, c}\right)$ & $1 \times 10^{5}$ A.m ${ }^{-2}[8]$ \\
\hline Electrolyte constant $(A)$ & $9 \times 10^{7} \mathrm{~K} \cdot \mathrm{ohm}^{-1} \cdot \mathrm{m}^{-1}[19]$ \\
\hline Electrolyte activation energy $\left(G_{a c t}\right)$ & $100 \times 10^{3}$ J.mol $^{-1}[19]$ \\
\hline Faraday constant $(F)$ & 96485 C.mole ${ }^{-1}$ \\
\hline Specific surface area $\left(A_{S}\right)$ & (Appendix A) [25] \\
\hline \multicolumn{2}{|l|}{ Thermal parameters } \\
\hline Anode effective thermal conductivity $\left(\lambda_{\text {effan }}\right)$ & $3 \mathrm{~W} \mathrm{~m}^{-1} \mathrm{~K}^{-1}[21]$ \\
\hline Anode convective heat transfer coefficient $\left(h_{a n}\right)$ & $57 \mathrm{~W} \mathrm{~m}^{-2} \mathrm{~K}^{-1} \quad[21]$ \\
\hline Cathode effective thermal conductivity $\left(\lambda_{\text {eff.cat }}\right)$ & $3.8 \mathrm{~W} \mathrm{~m}^{-1} \mathrm{~K}^{-1}[21]$ \\
\hline Cathode convective heat transfer coefficient $\left(h_{c a t}\right)$ & $49 \mathrm{~W} \mathrm{~m}^{-2} \mathrm{~K}^{-1}[21]$ \\
\hline Electrolyte effective thermal conductivity $\left(\lambda_{\text {eff }, e}\right)$ & $1.8 \mathrm{~W} \mathrm{~m}^{-1} \mathrm{~K}^{-1} \quad[21]$ \\
\hline \multicolumn{2}{|c|}{ Flow rate of fuel and air at the inlet } \\
\hline Fuel flow rate & $100 \mathrm{~mL}^{2} \mathrm{~min}^{-1}$ \\
\hline Air flow rate & $100 \mathrm{~mL}^{\mathrm{min}}{ }^{-1}$ \\
\hline \multicolumn{2}{|c|}{ Operating pressure and temperature of the cell } \\
\hline Operating pressure $(P)$ & $1 \mathrm{~atm}$ \\
\hline Operating temperature $(T)$ & $800^{\circ} \mathrm{C}$ \\
\hline
\end{tabular}




\section{Table 3}

\begin{tabular}{|c|c|}
\hline Parameters & Values \\
\hline Operating temperature $(T)$ & $800 \mathrm{C}^{\mathrm{o}}[22,23]$ \\
\hline Operating pressure $(P)$ & $1 \mathrm{~atm} \quad[22,23]$ \\
\hline Anode thickness $\left(t_{a n}\right)$ & $500 \mu \mathrm{m}[22,23]$ \\
\hline Anode porosity $\left(\varepsilon_{a n}\right)$ & $0.35[22]$ \\
\hline Anode tortuosity $\left(\tau_{a n}\right)$ & $3.8 \quad[22]$ \\
\hline Cathode thickness $\left(t_{c a t}\right)$ & $30 \mu \mathrm{m} \quad[22,23]$ \\
\hline Cathode porosity $\left(\varepsilon_{c a t}\right) \square$ & $0.35[22]$ \\
\hline Cathode tortuosity $\left(\tau_{c a t}\right)$ & $3.8 \quad[22]$ \\
\hline Specific surface area $\left(A_{S}\right)$ & $\begin{array}{c}3 \times 10^{6} \mathrm{~m}^{2} \cdot \mathrm{m}^{-3} \\
{[8,22]}\end{array}$ \\
\hline Electrolyte thickness $\left(t_{e}\right)$ & $25 \mu \mathrm{m} \quad[22,23]$ \\
\hline
\end{tabular}

\section{Figures}

Figure 1(a)

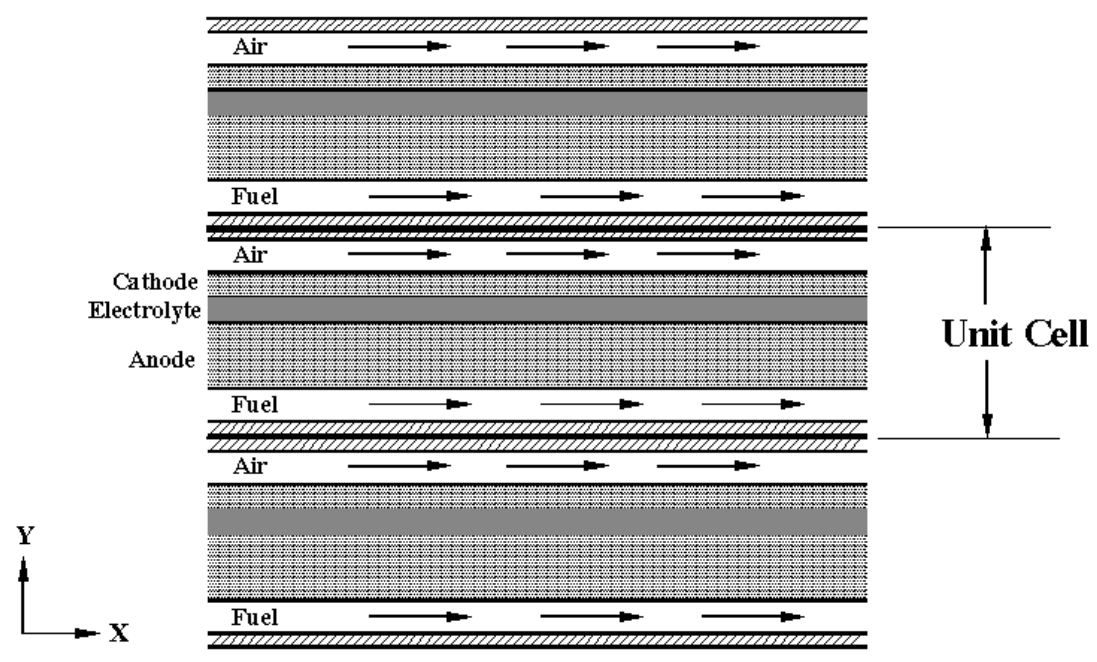

All dimensions not to scale

Figure 1(b)

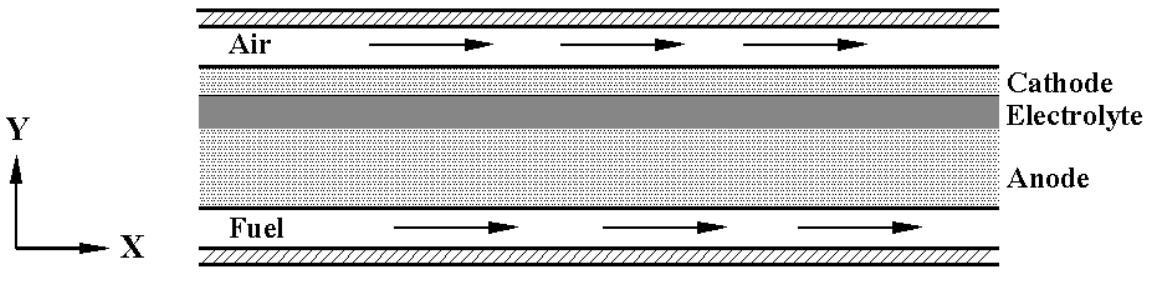

All dimensions not to scale 
Figure 2

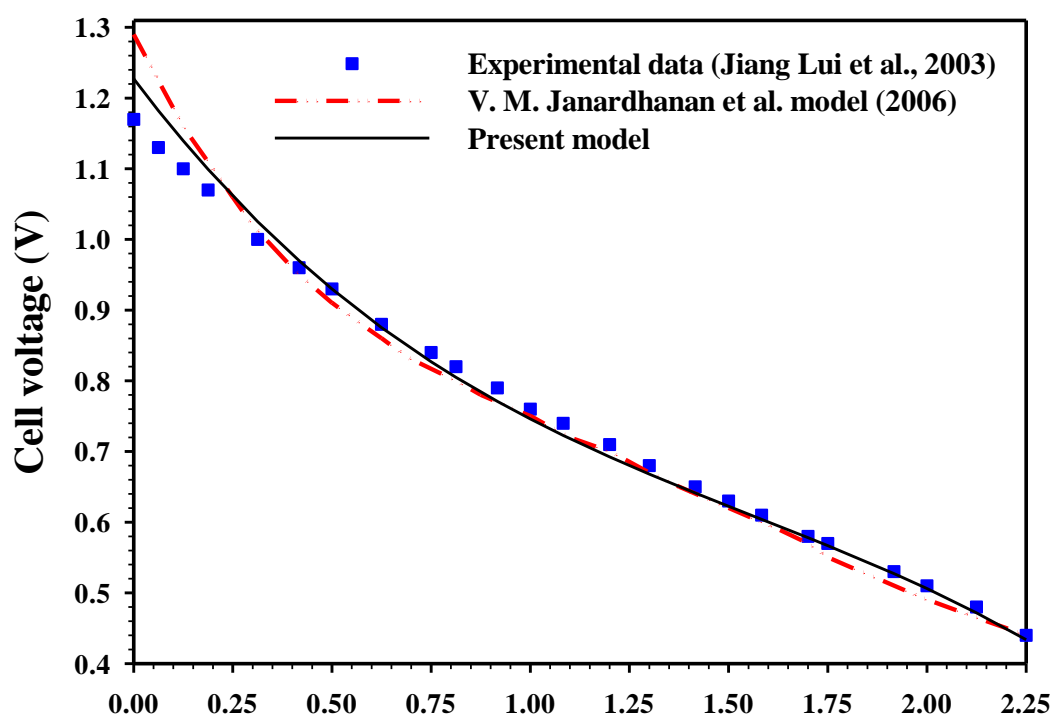

Current density $\left(\mathrm{A} / \mathrm{cm}^{2}\right)$

Figure 3

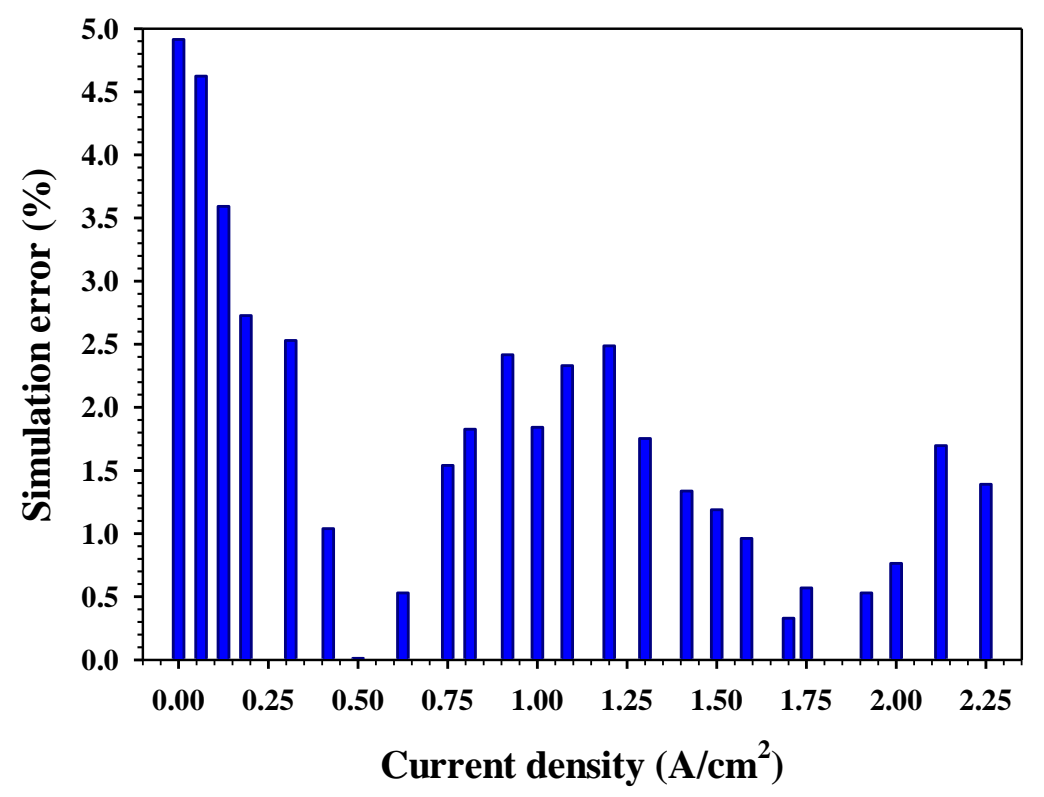

Figure 4 (a)

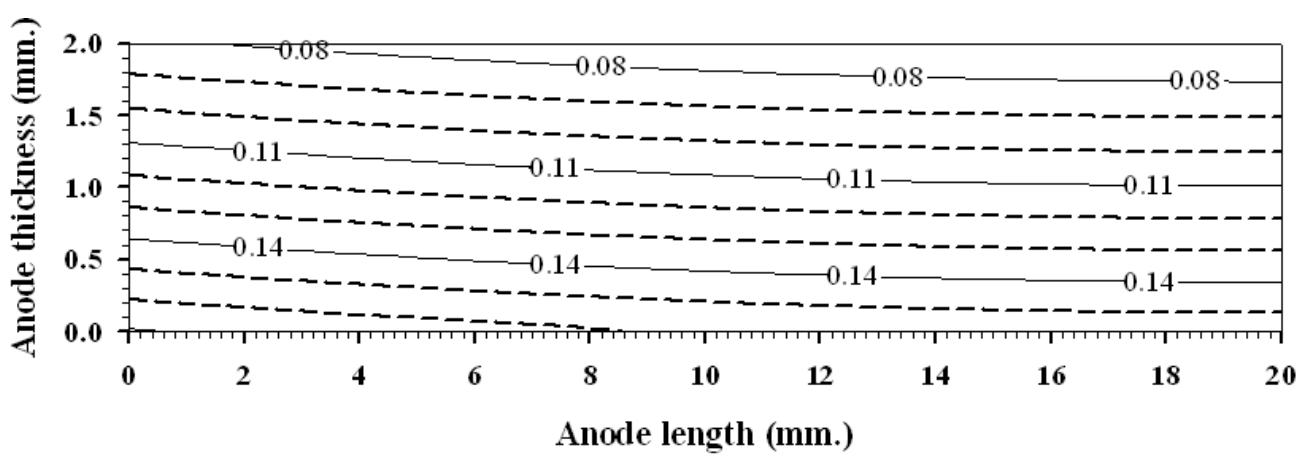


Figure 4 (b)

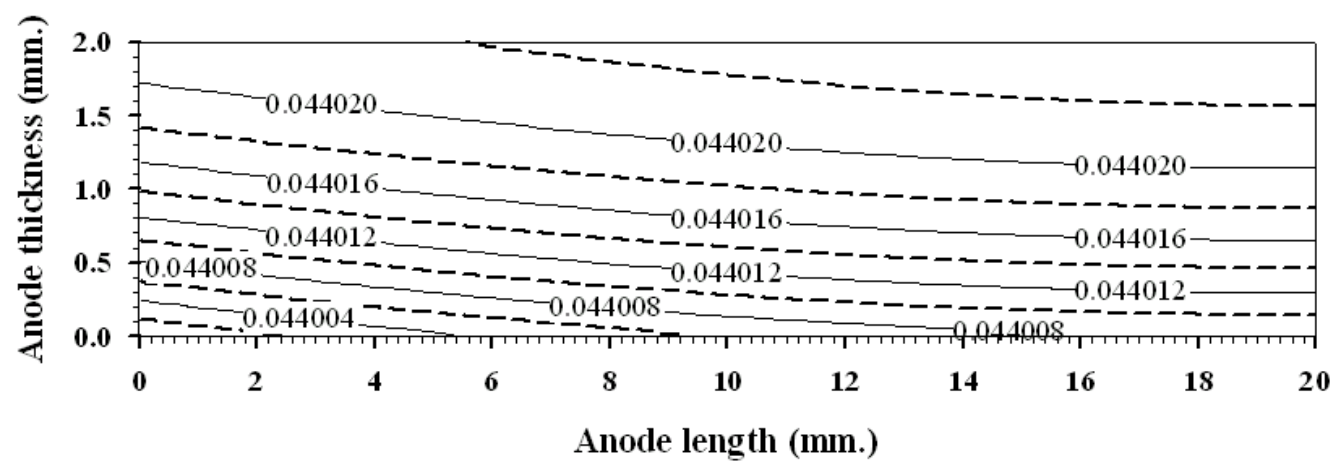

Figure 4 (c)

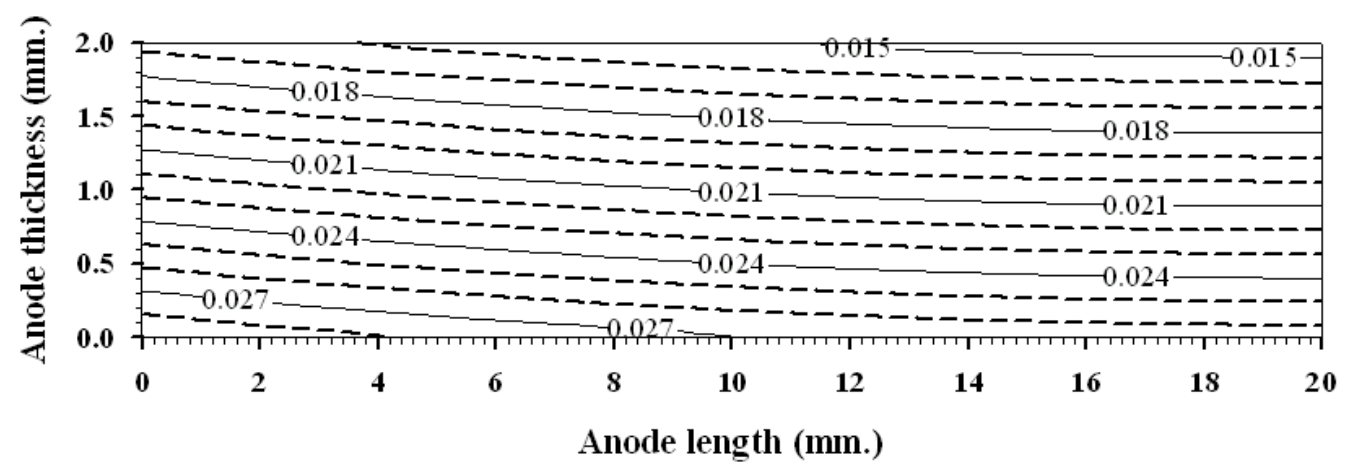

Figure 4 (d)

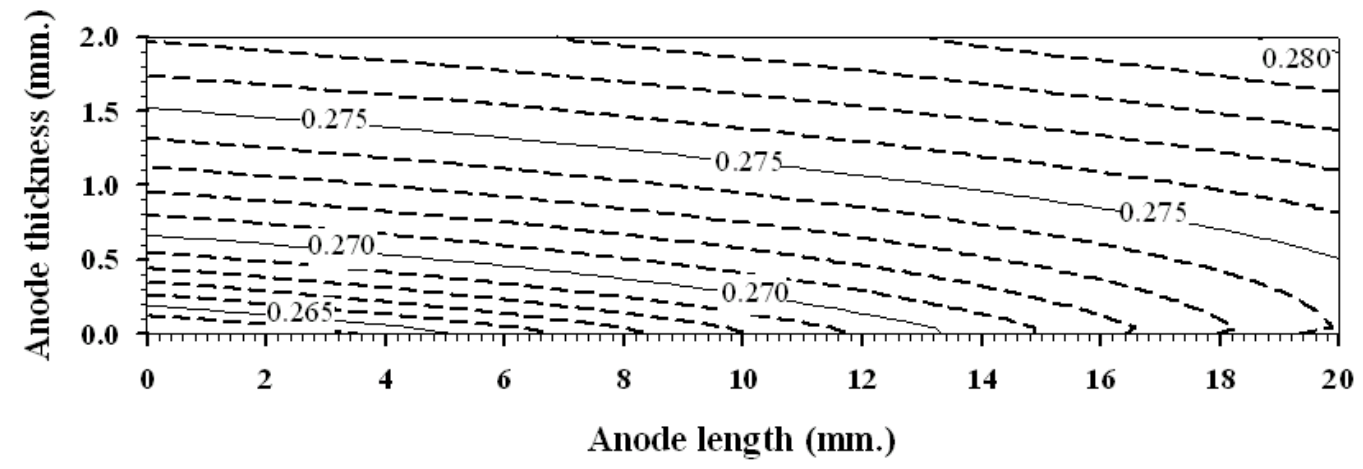

Figure 4 (e)

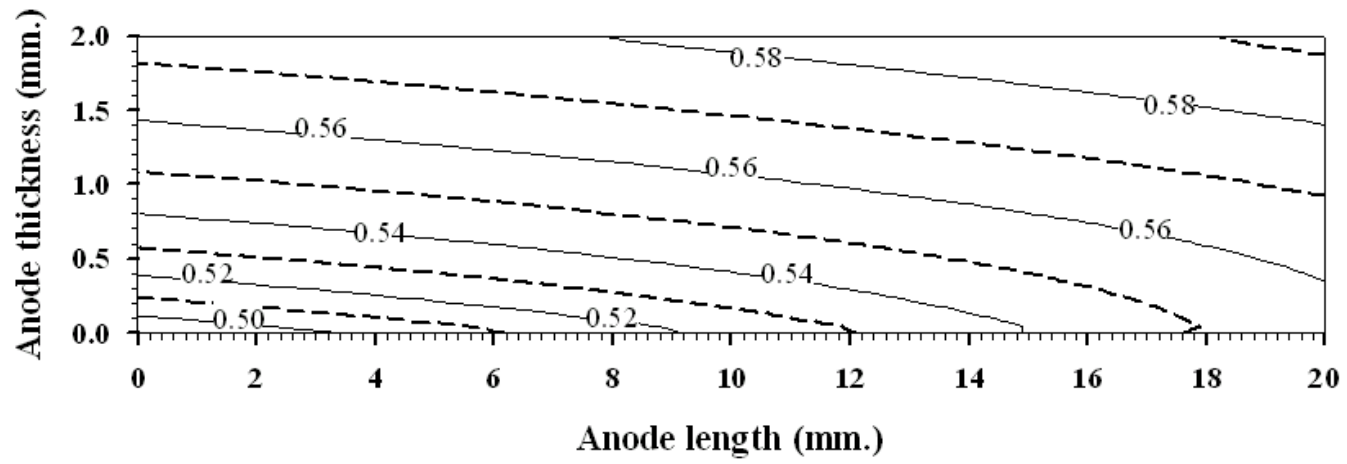


Figure 5

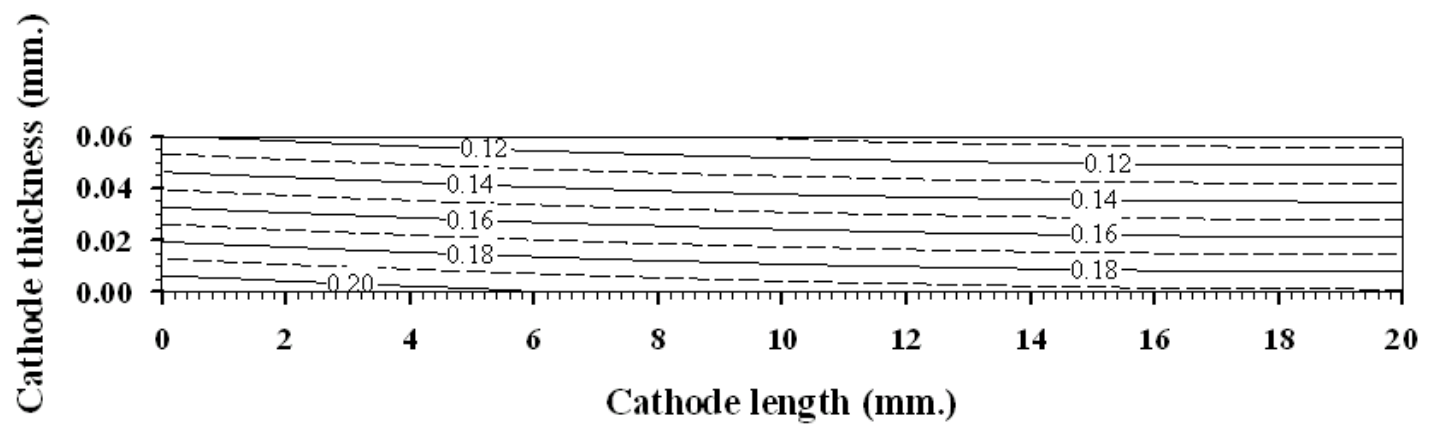

Figure 6 (a)

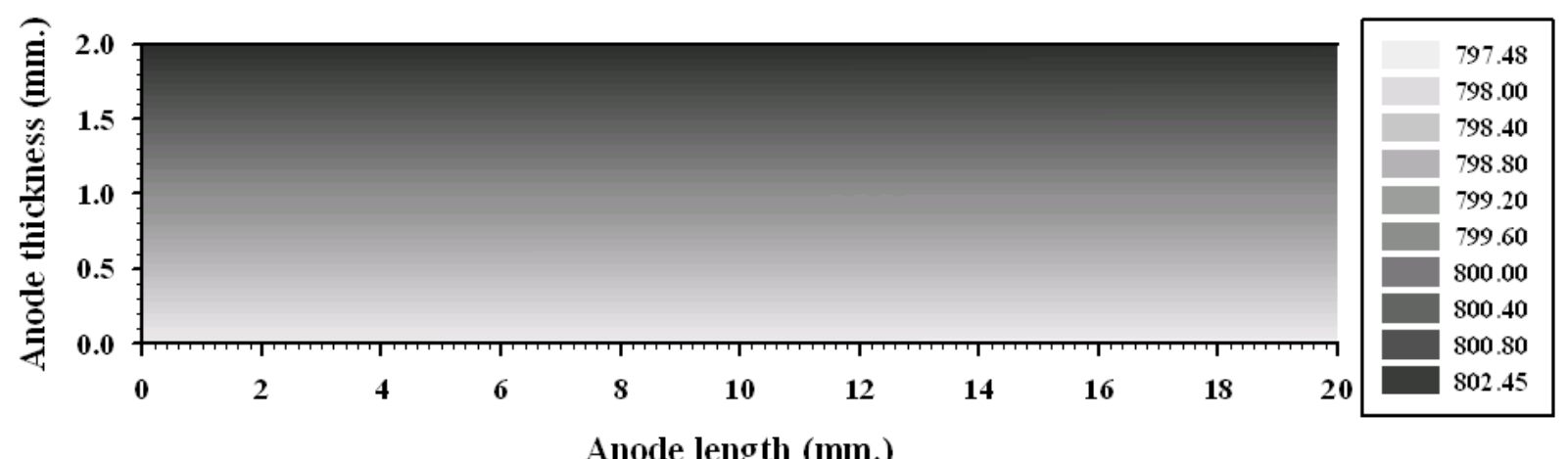

Figure 6 (b)

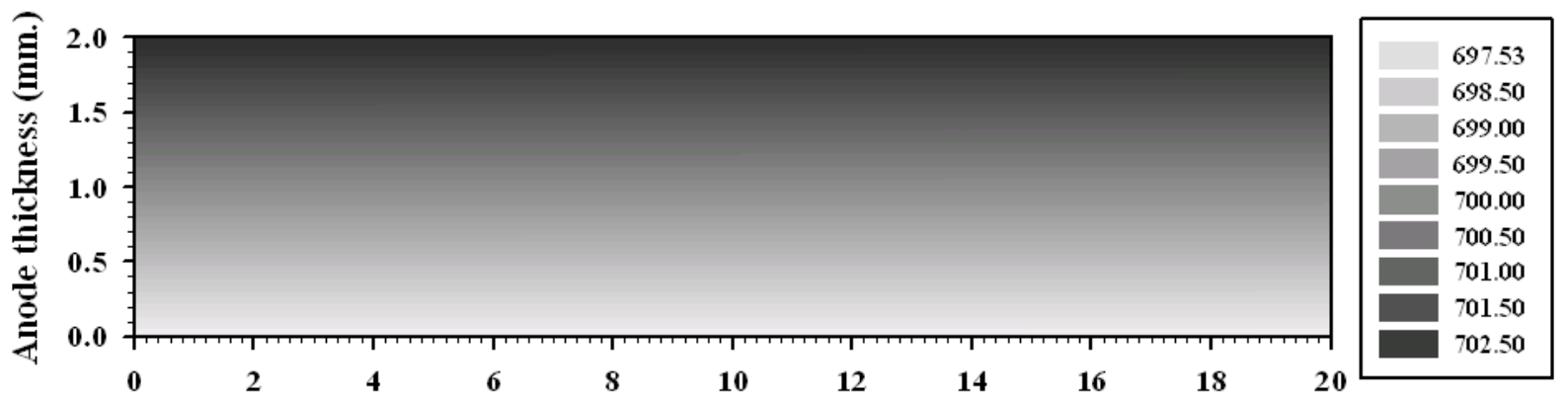

Anode length (mm.)

Figure 6 (c)

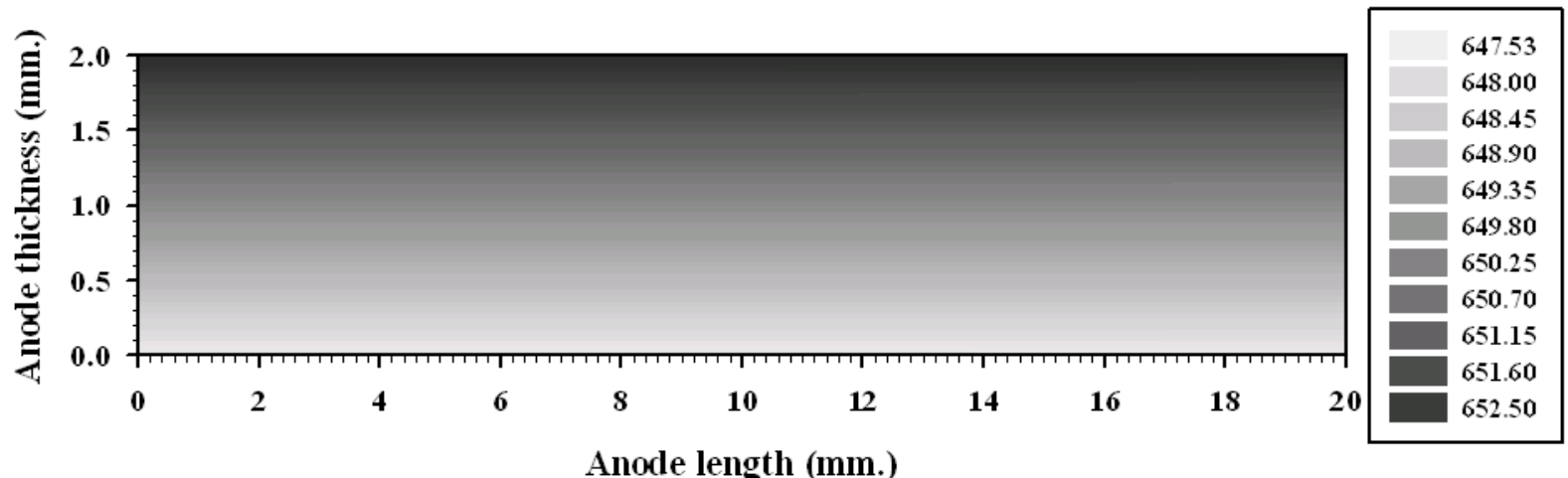


Figure 7

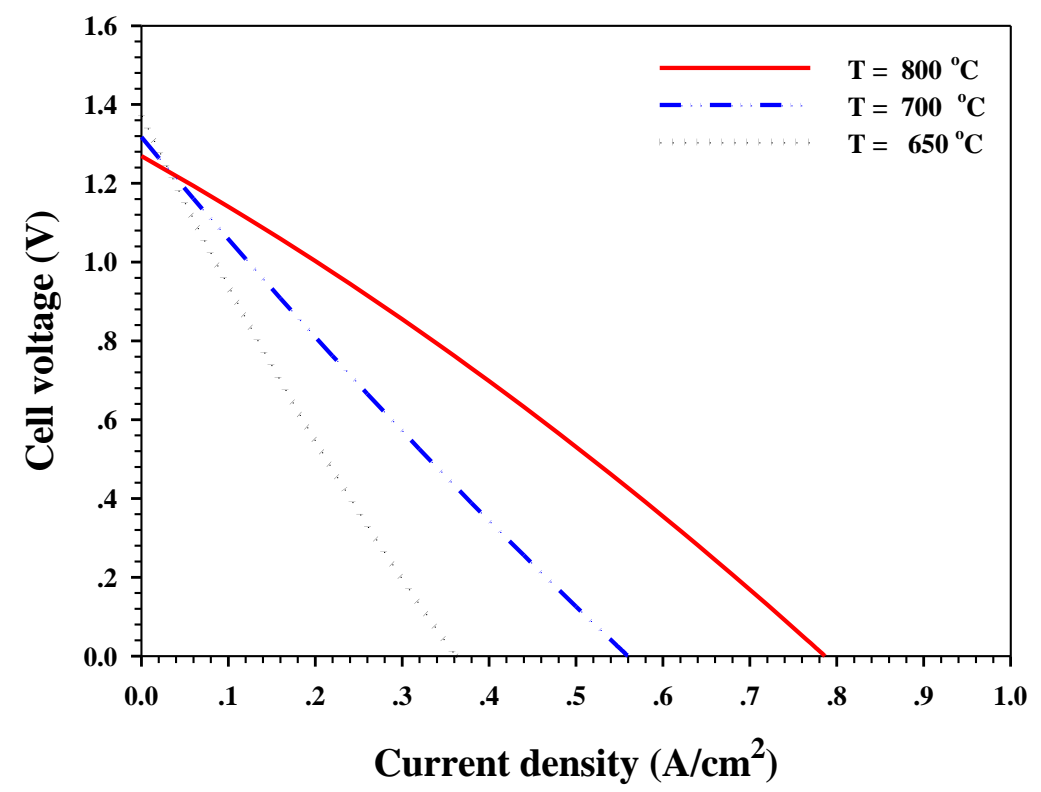

Figure 8

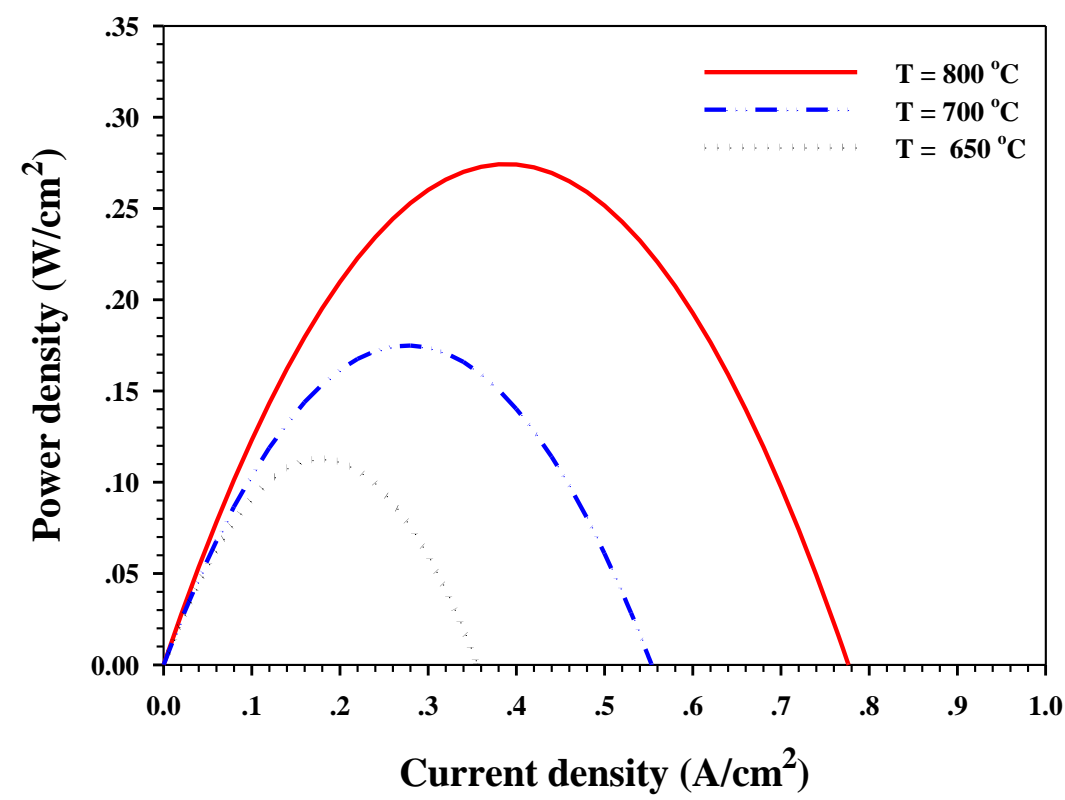


Figure 9

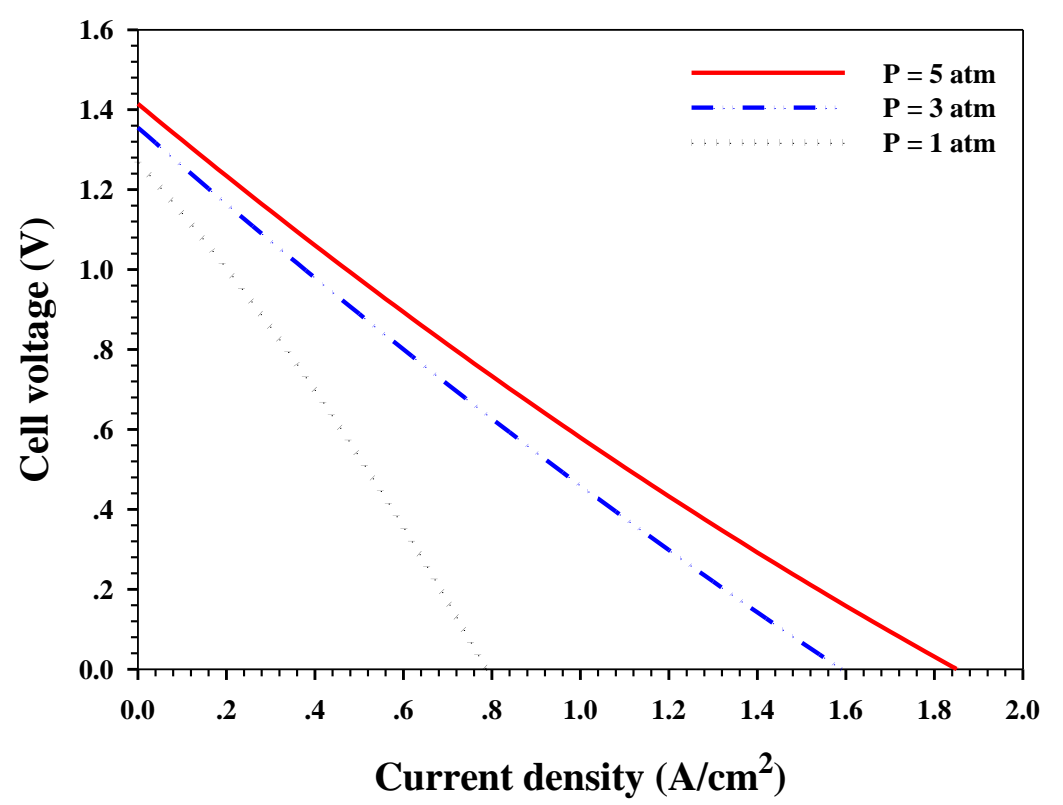

Figure 10

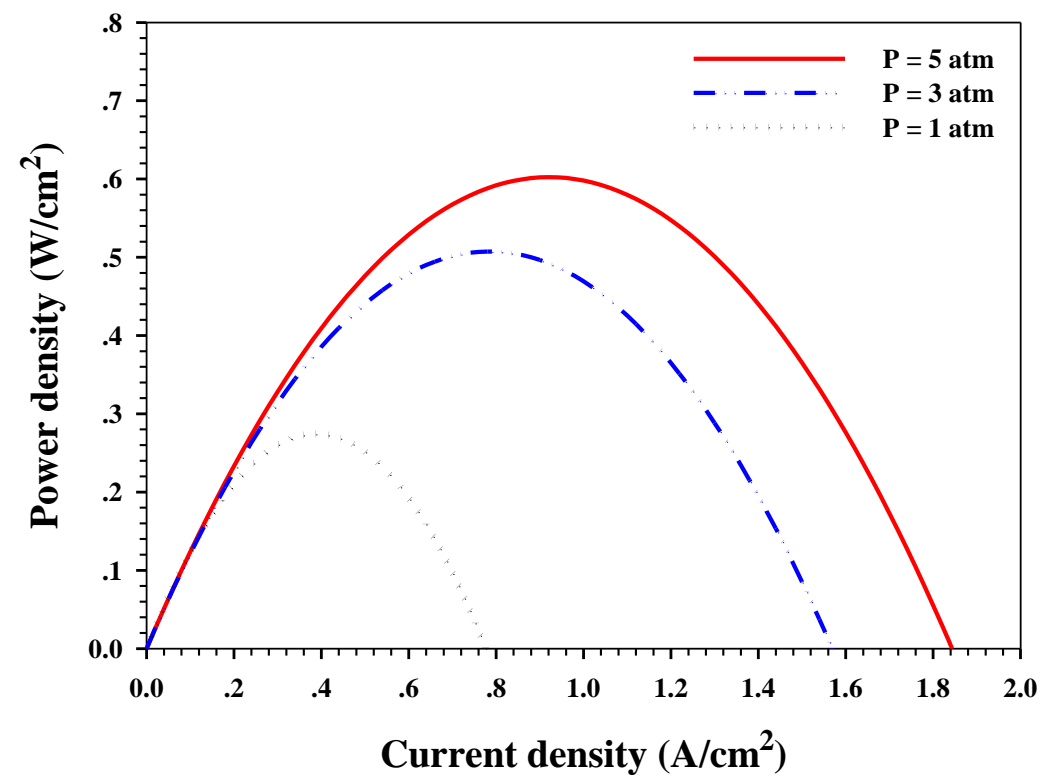


Figure 11

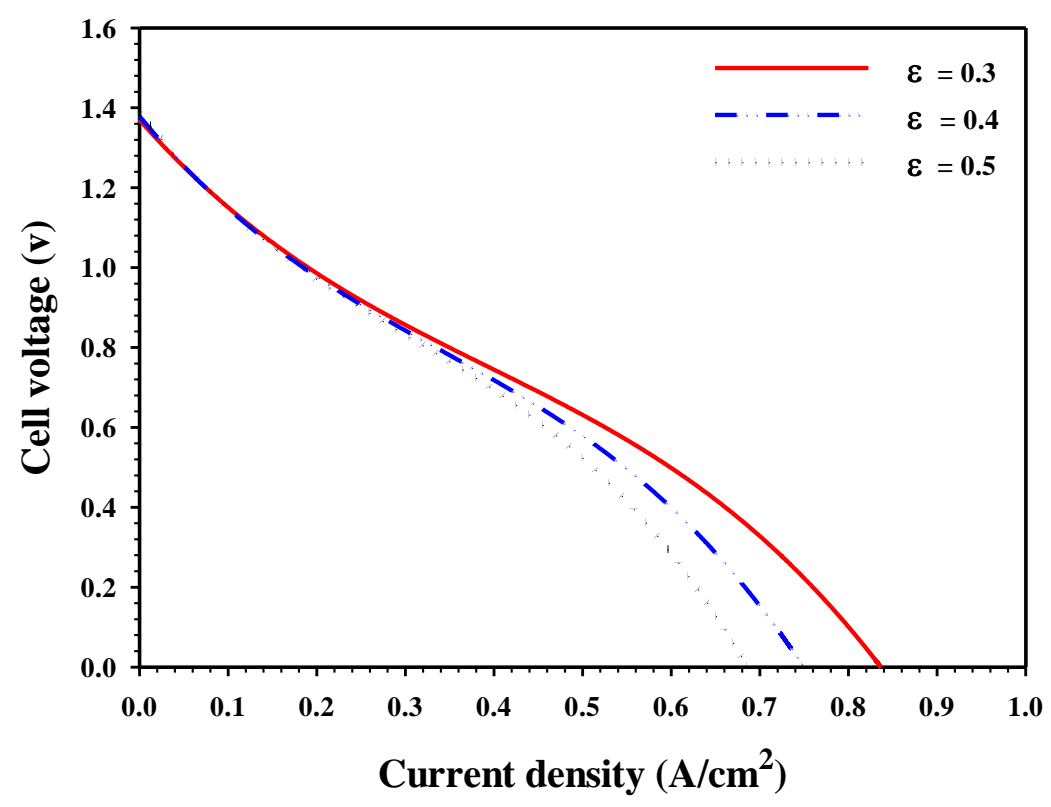

Figure 12

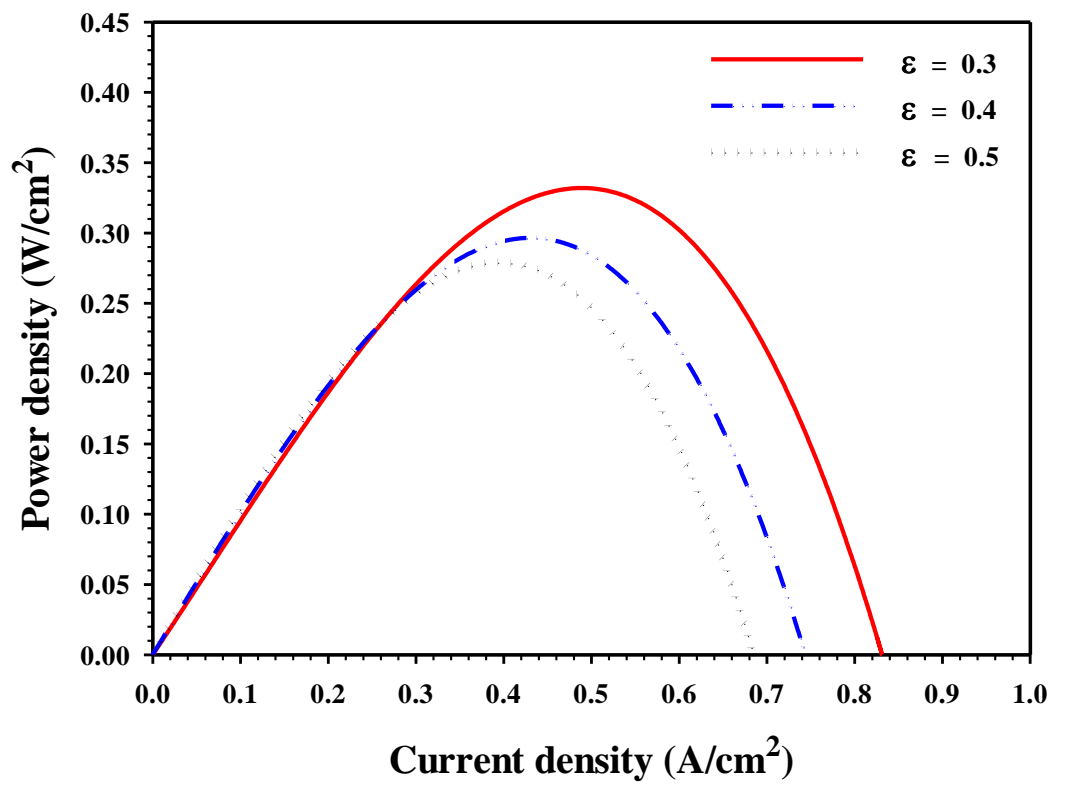


Figure 13

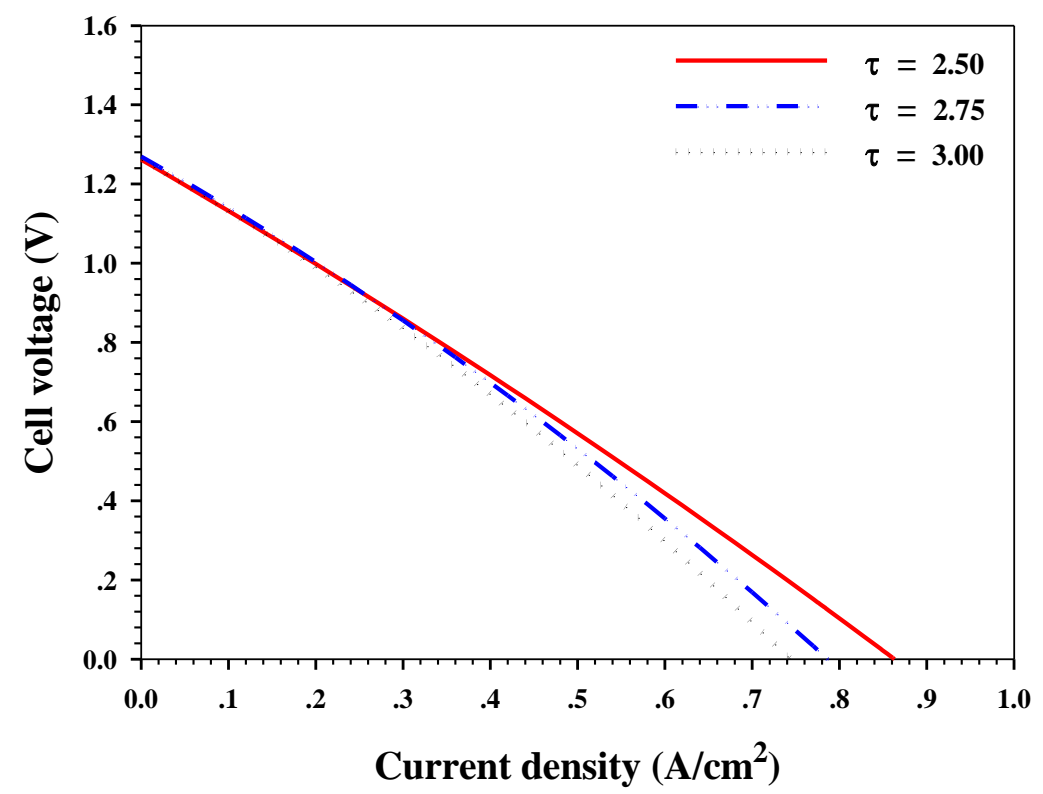

Figure 14

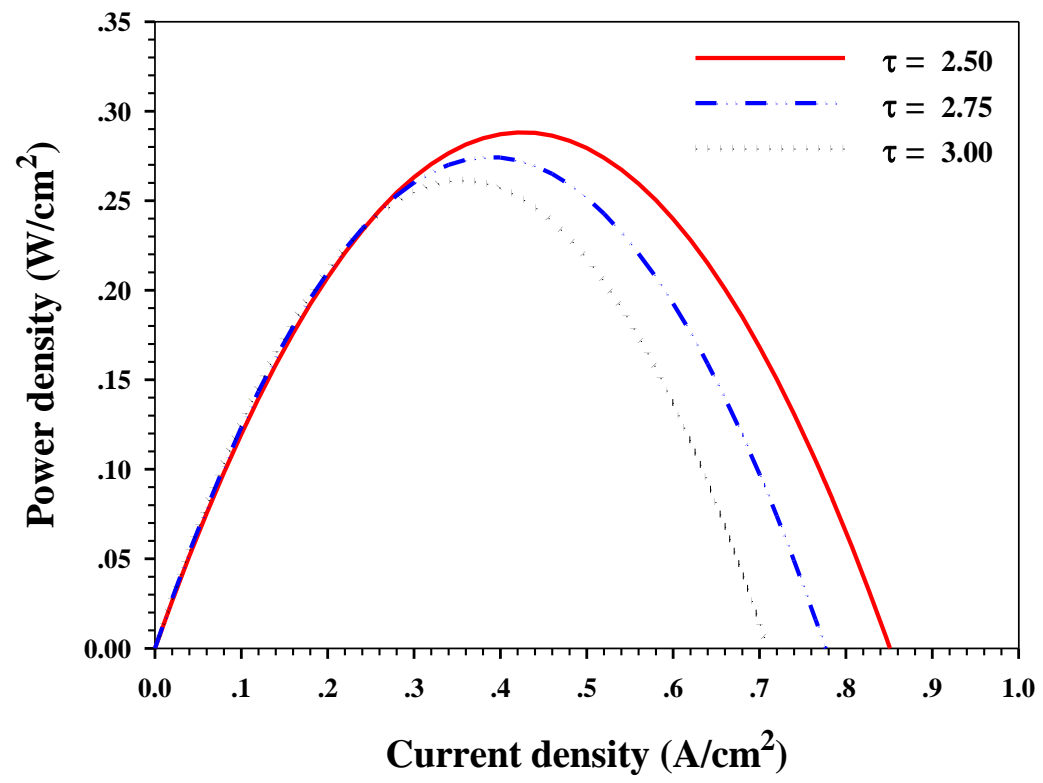


Figure 15

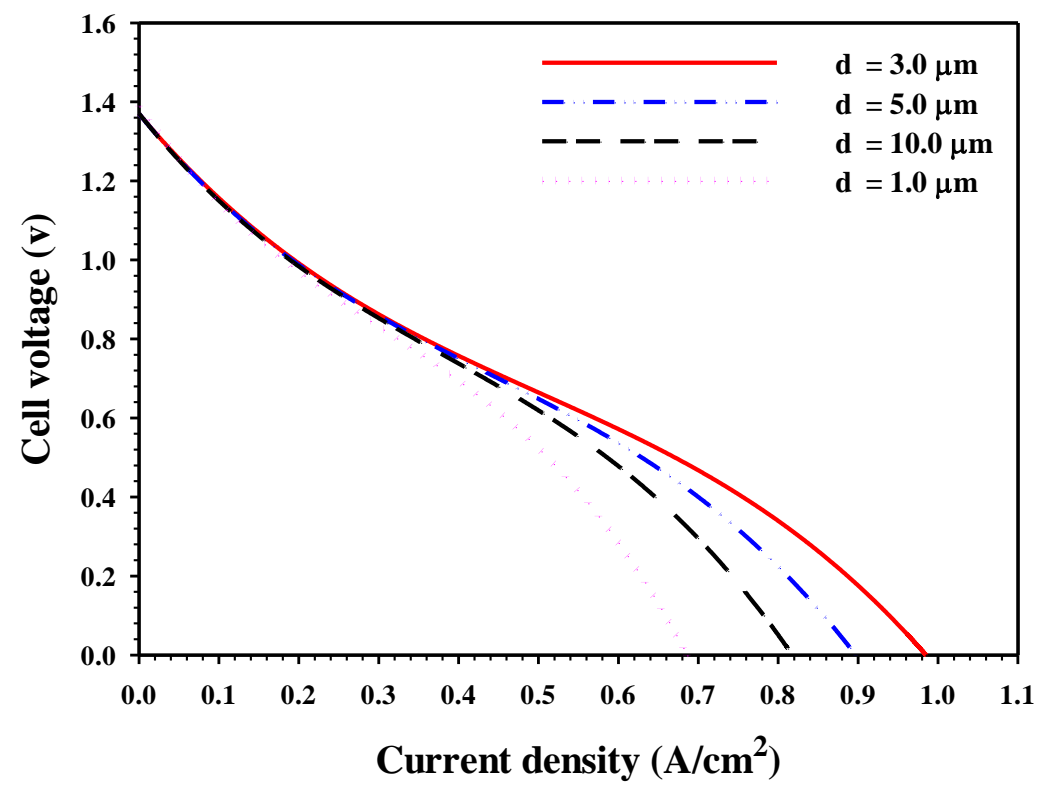

Figure 16

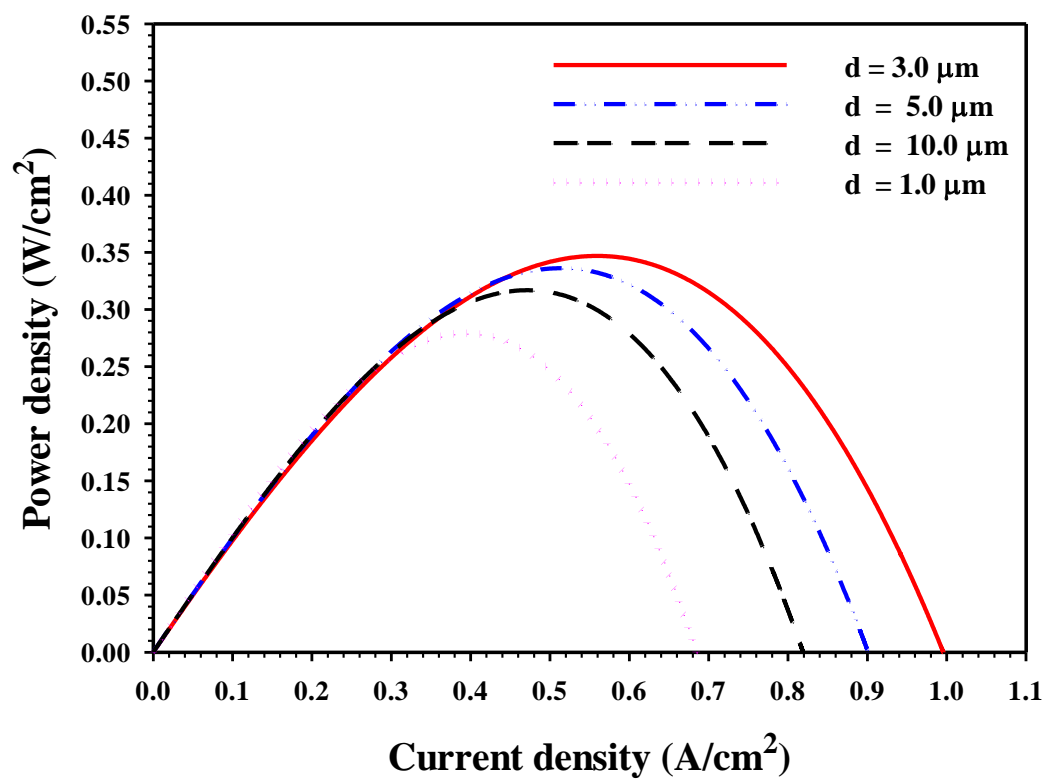


Figure 17

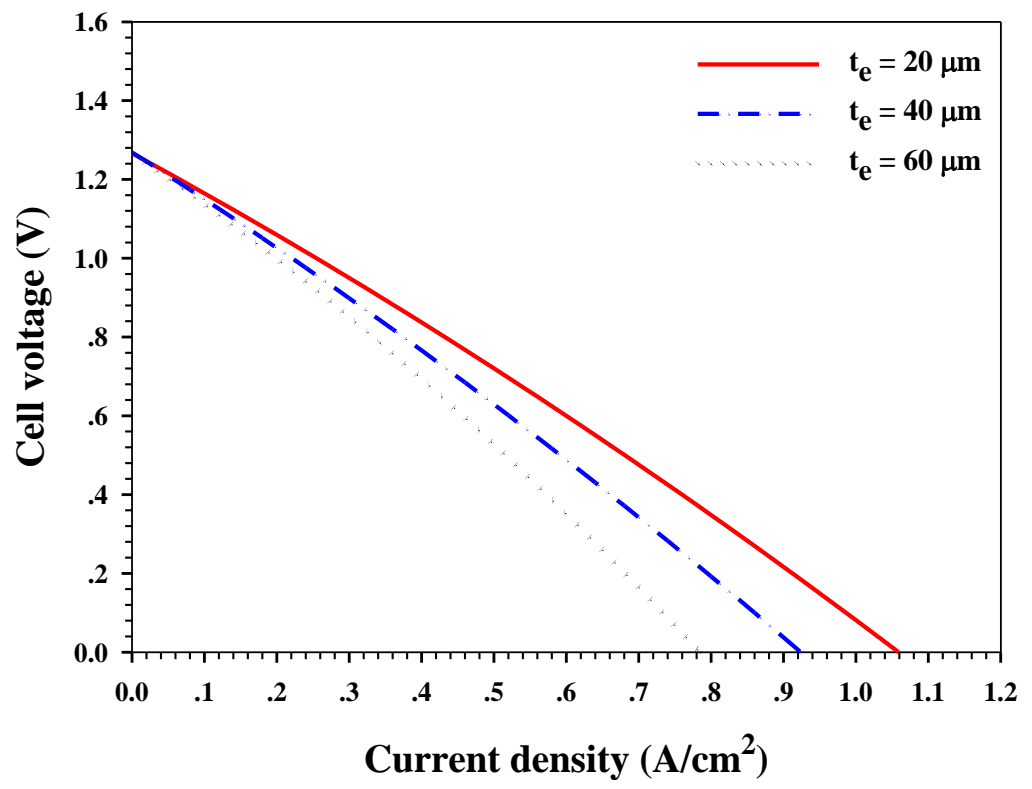

Figure 18

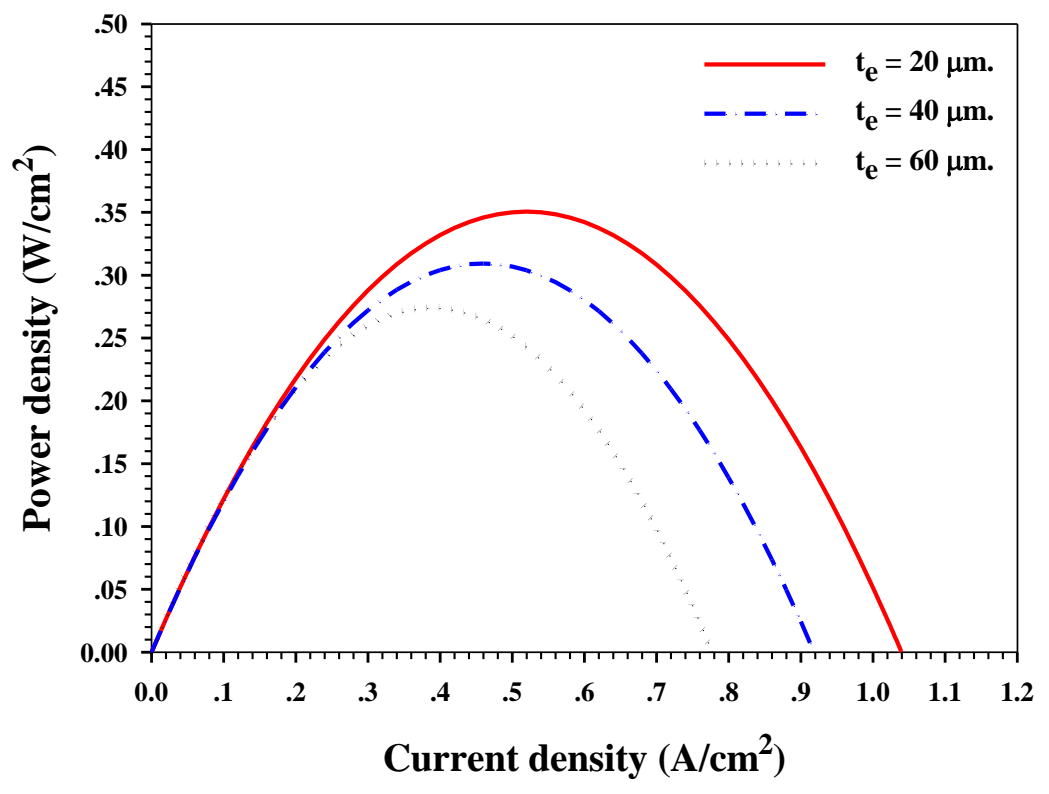

